\title{
Lusioersily
}

\section{A review of energy optimization modelling tools for the decarbonisation of wastewater treatment plants}

Nakkasunchi, S., Hewitt, N., Zoppi, C., \& Brandoni, C. (2021). A review of energy optimization modelling tools for the decarbonisation of wastewater treatment plants. Journal of Cleaner Production, 279, [123811].

https://doi.org/10.1016/j.jclepro.2020.123811

Link to publication record in Ulster University Research Portal

Published in:

Journal of Cleaner Production

Publication Status:

Published (in print/issue): 10/01/2021

DOI:

10.1016/j.jclepro.2020.123811

\section{Document Version}

Author Accepted version

\section{General rights}

Copyright for the publications made accessible via Ulster University's Research Portal is retained by the author(s) and / or other copyright owners and it is a condition of accessing these publications that users recognise and abide by the legal requirements associated with these rights.

\section{Take down policy}

The Research Portal is Ulster University's institutional repository that provides access to Ulster's research outputs. Every effort has been made to ensure that content in the Research Portal does not infringe any person's rights, or applicable UK laws. If you discover content in the Research Portal that you believe breaches copyright or violates any law, please contact pure-support@ulster.ac.uk. 


\title{
A review of energy optimization modelling tools for the decarbonisation of wastewater treatment plants
}

\author{
Shalini Nakkasunchi*a ${ }^{*}$ Neil J Hewitt ${ }^{\mathrm{a}}$, Claudia Zoppi ${ }^{\mathrm{b}}$ and Caterina Brandoni ${ }^{\mathrm{a}}$
}

*Corresponding author: Nakkasunchi-S@ulster.ac.uk

a Centre for Sustainable Technologies, Belfast School of Architecture and the Built Environment, Faculty of Computing, Engineering and the Built Environment, University of Ulster, Newtownabbey, County Antrim BT37 0QB, United Kingdom.

${ }^{\mathrm{b}}$ Aset Spa, Wastewater utility, Via Enrico Mattei 17, Fano PS 61032, Italy.

\section{Abstract}

Wastewater treatment plants strongly contribute to the Greenhouse Gas emissions of the water industry and are responsible for the $3 \%$ of the global energy demand. This proportion of energy is expected to double in the coming decade. It is therefore important to correctly investigate the optimal use of energy in wastewater treatment facilities that can reduce their Greenhouse Gas emissions. A review was developed on modelling tools that can be used for the analysis of the water-energy nexus in wastewater facilities, from over 200 research articles collected from different scientific resources published in the last 15 years. The aim was to analyse the state of art of existing tools to provide an aid for researchers and professionals to identify the most suitable tool to investigate decarbonisation strategies for wastewater facilities. Studies were grouped on the basis of the main intervention analysed: i) reduction of energy demand, ii) energy production from wastewater and iii) integration of the available renewable sources on-site (e.g. PV, hydro). The work developed also provides an overview of the most applicable decarbonisation strategies and their potential to reduce the $\mathrm{CO}_{2}$ emissions of wastewater facilities. Results show that identifying the best tool strongly depends on the main aim of the intervention. Existing tools, in fact, can help to analyse separately either technologies to reduce the energy demand or the integration of the most common renewable sources from both wastewater (i.e. biogas and heat recover) and renewable sources exploitable on site. However, the full decarbonisation of wastewater facilities can only happen by integrating different energy savings and renewables solutions. There is, therefore, the need for a comprehensive energywater optimization tool able to understand how key water parameters influence the energy demand and to identify, on a single platform, the best energy saving solutions and the benefits coming from integrating different renewable sources. Such platform could help in enhancing 
32 the benefits of combined solutions, helping to maximise the reuse of the renewable energy produced onsite and any opportunity of energy savings.

\section{$34 \quad$ Keywords}

35 Modelling tools, Wastewater treatment, Energy optimization, Energy recovery, Renewable 36 energy.

37

Aerobic and Anoxic

Alternative current

$\mathrm{A}^{2} \mathrm{O}$

AAS

AD

Anoxic-Anaerobic-Oxic

$\mathrm{A}_{\mathrm{T}}$

AFF

AFR

$\mathrm{A} / \mathrm{O}$

ASPs

BNR

- Wastewater treatment plants account for $56 \%$ greenhouse gas emissions of the water industry.

- An overview of potential energy decarbonisation strategies is presented.

- Analysis of energy optimisation tools for wastewater treatment plants is developed.

- Modelling tools for assessing either the energy benchmarking or renewables are available

- Need to integrate energy benchmarking, resource recovery and renewables in a single platform.

Altering activated sludge process

Anaerobic digester

Alkalinity

Artificial neural network

Average flow rate

Anaerobic/Oxic

Activated sludge process

Biological nitrogen removal 


\begin{tabular}{|c|c|}
\hline BOD & Bio-chemical oxygen demand \\
\hline CHP & Combined heat and power \\
\hline CLEW & Climate, Land-use, Energy and Water \\
\hline COD & Chemical oxygen demand \\
\hline $\mathrm{DC}$ & Direct current \\
\hline DO & Dissolved oxygen \\
\hline DS & Dry solid content \\
\hline DYNO & Dynamic optimization solver \\
\hline $\mathrm{EB}$ & Energy benchmarking \\
\hline $\mathrm{EC}$ & Electro-coagulation \\
\hline ED & Energy demand \\
\hline EED & Electrical energy demand \\
\hline EO & Electro-oxidation \\
\hline EOS & Energy Online System \\
\hline ER & Energy recovery \\
\hline EQ & Effluent quality \\
\hline FL & Fuzzy logic \\
\hline FOG & Fat, oil and grease \\
\hline FR & Flow rate \\
\hline GA & Genetic algorithm \\
\hline GAMS & General Algebraic Modelling Software \\
\hline GHGs & Greenhouse gases \\
\hline HP & Heat pump \\
\hline HRT & Hydraulic retention time \\
\hline
\end{tabular}




\begin{tabular}{|c|c|}
\hline IRENA & International Renewable Agency \\
\hline KPIs & Key performance indicators \\
\hline LBE-INRA & Inra-Lbe Laboratorie De Biotechnologie De L'environnement \\
\hline LIST & Luxembourgh Institute of Science and Technology \\
\hline MBR & Membrane bioreactor \\
\hline $\mathrm{MC}$ & Moisture content \\
\hline mgd/MGD & Million gallons per day \\
\hline MFC & Microbial fuel cell \\
\hline MHP & Micro-hydropower \\
\hline MLE & Modified Ludzack-Ettinger \\
\hline MR & Maximizing revenue \\
\hline MTC & Minimization of total cost of the system \\
\hline MuSIASEM & Multi-scale Integrated Analysis of Societal and Ecosystem Metabolism \\
\hline NexSym & Nexus Simulation System \\
\hline $\mathrm{N}$ & Nitrogen \\
\hline $\mathrm{N}_{2} \mathrm{O}$ & Nitrous oxide \\
\hline $\mathrm{NH}_{3}$ & Ammonia concentration \\
\hline $\mathrm{NH}_{3}-\mathrm{N}$ & Ammonical nitrogen content \\
\hline $\mathrm{NO}_{2}^{-}$ & Nitrite concentration \\
\hline $\mathrm{NO}_{3}^{-}$ & Nitrate concentration \\
\hline NPV & Net present value \\
\hline NR & Nutrient recovery \\
\hline $\mathrm{OL}$ & Organic load \\
\hline PE & People equivalent \\
\hline
\end{tabular}


PNS Process Network Synthesis

PRIMA Platform for Regional Integrated Modelling and Analysis

PV Photovoltaic

$\mathrm{R}_{1} \quad$ Reduce

$\mathrm{R}_{2} \quad$ Recover

$\mathrm{R}_{3} \quad$ Renewables

RE Renewable energy

RF Rainfall/precipitation

SCMFC Single cell microbial fuel cell

SHC Specific heat capacity

SHP Small hydropower

SMBR Single membrane bioreactor

SMC Sludge moisture content

SPSS Statistical Package for Social Sciences

SRR Sludge recycling rate

SRT Solid retention time

SS Suspended solids

SS-AD Solid state anaerobic digester

SSTP Sewage sludge treatment process

SWW Solid waste and wastewater management system

TED Thermal energy demand

TF Trickling filter

TIAM-FR TIMES Integrated Assessment Model

TIMES The Integrated MARKAL-EFOM System 


\begin{tabular}{|c|c|}
\hline $\mathrm{TN}$ & Total nitrogen \\
\hline TOC & Total organic carbon \\
\hline ТP & Total phosphorous \\
\hline TS & Total solids \\
\hline TSS & Total suspended solids \\
\hline UAMFC & Up-flow anaerobic microbial fuel cell \\
\hline UASB & Up-flow anaerobic sludge blanket \\
\hline USEPA & United States Environmental Protection Agency \\
\hline UV & Ultraviolet \\
\hline VFA & Volatile fatty acids \\
\hline VS & Volatile solids \\
\hline VSS & Volatile suspended solids \\
\hline $\mathrm{W}$ & Watt \\
\hline WC & Water content \\
\hline WEF & Water-Energy-Food \\
\hline WEFO & Water-Energy-Food Security Nexus Optimization \\
\hline WR & Water resources \\
\hline WRRF & Water Resource Recovery Facilities \\
\hline WW & Wastewater \\
\hline WSHP & Water source heat pump \\
\hline WWSHP & Wastewater source heat pump \\
\hline WWT & Wastewater treatment \\
\hline WWTPs & Wastewater treatment plants \\
\hline
\end{tabular}




$\begin{array}{ll}\% & \text { Percentage } \\ \mathrm{H} & \text { Efficiency } \\ \checkmark & \text { Applicable } \\ \mathrm{X} & \text { Not applicable }\end{array}$

\section{Introduction}

Wastewater treatment plants (WWTPs) account for about $56 \%$ of the greenhouse gas (GHG) emissions among the water industry (Ainger et al., 2009). Concentration of the GHGs above the permissible limit in the environment can lead to global warming, formation of smog and haze, acid rains, acidification of oceans and photochemical oxidation (USEPA, 2013). Numerous onsite processes like degradation of biosolids by aerobic treatment process, dewatering and degradation of sludge are the direct contributors of GHGs into the environment (Sweetapple et al., 2013). However, direct GHG emissions from WWTPs are not accounted under the carbon footprint calculations due to their biogenic origin (Griffiths-Sattenspiel and Wilson, 2009). The present paper will focus on indirect GHG emissions coming from the energy consumption (mainly electricity) of WWTPs, which is recognised as the major source of their GHG emissions (Hao et al., 2015). Globally, about 3-5\% of the electricity is used by WWTPs (McCarty et al., 2011). Considering the 2019 electricity global demand and a $\mathrm{CO}_{2}$ emission factor for electricity of $475 \mathrm{gCO}_{2} / \mathrm{kWh}$ (EPA, 2019), it means 350 million ton of $\mathrm{CO}_{2}$ per year, that it is almost the $\mathrm{CO}_{2}$ emission of the entire UK. The $20 \%$ of this value comes from the energy used for fully treated wastewater (WW) and the $80 \%$ from partially treated WW. Today over $80 \%$ of the WW produced is directly discharged into the environment without proper treatment (UNESCO, 2017), creating major problem on the environment and people health. The problem will need to be addressed and as a result, energy analysts expect that the energy demand for WW treatment plants will double by 2050 (World Energy Outlook, 2019).

Looking at existing review papers on the use of energy in wastewater facilities (water-energy nexus), authors have either discussed and reviewed energy benchmarking data (Longo et al., 2016) to provide target parameters to understand how energy is used in the facility or have discussed and compare different decarbonisation strategies. For examples, Gu et al. (2017) 
have looked in details at energy recovery technologies like anaerobic digesters (AD), microbial fuel cells (MFC), algal biofuels and heat pumps. Larsen (2015) has discussed the opportunities coming from thermal energy recovery from household and sewer WW, and the optimization of aerobic treatment process and nutrient recovery. Bastone and Virdis (2014) reviewed the economic feasibility of low energy intensive nutrient recovery processes, like annamox and chemical precipitation and energy recovery process, like AD. Gude (2015) reviewed different energy recovery technologies such as chemical $\mathrm{AD}, \mathrm{MFC}$, algal biofuels and microbial desalination cell), thermal (heat pump) and hydraulic (hydropower) to understand how to transform energy intensive WWTPs into energy positive facilities. Mo and Zhang (2013) reviewed the water reuse opportunities and nutrient recovery technologies to reduce the energy consumption and management cost of wastewater facilities. Venkatesh et al (2014) examined the key factors influencing the carbon emissions of the water industry (including collection and treatment of WW) by analysing four case studies belonging to four different cities.

The analysis of existing studies shows that researchers have analysed and reviewed either a single or a combination of decarbonisation strategies, but none of them have looked at the modelling tools that can be used for the analysis. The present paper fills the gap with the aim to guide researchers and professionals to identify the best tools to assess the optimal use of energy in WW facilities. Furthermore, the study of the tools used in literature has provided the opportunity to critical analyse the most common decarbonisation strategies and compare their potential to reduce the $\mathrm{CO}_{2}$ emissions.

Selection of resources and screening of the data for developing this review is detailed in Section 2. Section 3, 4 and 5 give an overview of the modelling tools and low carbon strategies aimed at, respectively, reducing the energy demand, recover energy from wastewater and integrate renewable sources onsite. Section 6 compares the different models and show the potential to reduce the $\mathrm{CO}_{2}$ emissions from different decarbonisation strategies. Finally, section 7 provides the conclusive remarks.

\section{Methodological approach}

Methodological workflow adopted in developing this review is given in Figure 2. In order to review the modelling tools and strategies to reduce the energy demand for WWTP decarbonisation, resources were rigorously searched from Scopus. The terminology used in finding the relevant resources are 'water energy nexus', 'wastewater energy consumption', 
'low carbon wastewater treatment', 'wastewater energy optimization', 'energy from wastewater', 'renewables for wastewater' and 'sustainable wastewater treatment. Other resources like Government and Environmental Agency reports, technical guides and reports on/by WWTPs were also collected for understanding how energy is used in different processes. Overall, 220 resources were gathered for this study. Further to this, looking at the selected literature we have identified the modelling tools used for the analysis. The result is 43 resources that will be discussed in the following sections. Based on the main aim of the decarbonisation strategy analysed we have grouped the studies into three categories i.e., Reduce, Recover and Renewables (3R's) (Figure 1).

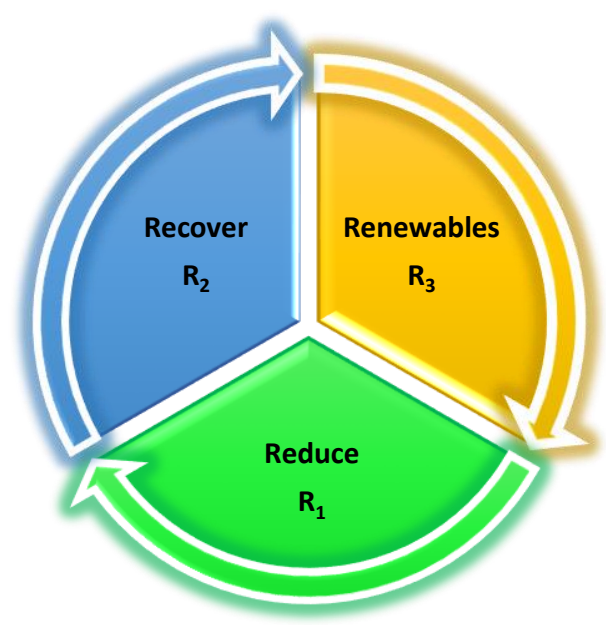

Figure 1: Categories used to group the studies analysed.

The category "Reduce $\left(\mathrm{R}_{1}\right)$ " looks at tools to reduce the energy demand of processes and devices, such as replacing pumps and air blowers. Although being waste, WW is a source of energy estimated to be 9-10 higher than the energy used for WW treatments (Shizas and Bagley, 2004). Modelling aimed at optimising the energy recovery potential and the respective technologies are categorised as "Recover $\left(\mathrm{R}_{2}\right)$ ". WWTPs have also a good opportunity of generating their own energy by exploiting local available renewable energy resources like solar, hydro and wind. Such tools are categorised as "Renewables $\left(\mathrm{R}_{3}\right)$ ". 


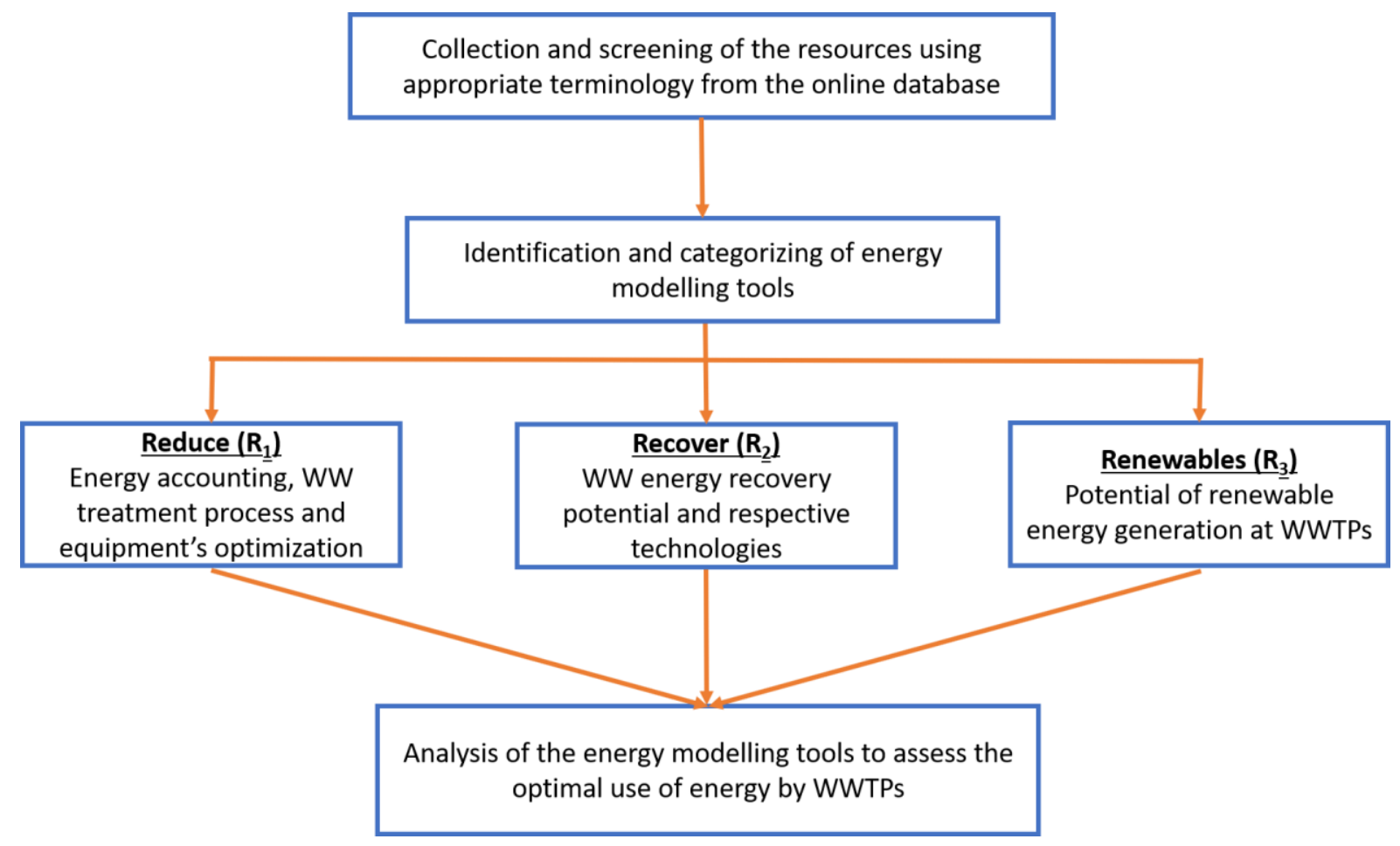

$125 \quad$ Figure 2: Methodological approach adopted

127 The main purpose of WWTPs is to protect the public health and the environment and, when 128 possible, reduce the water scarcity through the water reuse (Massoud, Taehini and Nasr, 2008).

129 Treatment of WW occurs in 5 stages at WWTPs such as preliminary, primary, secondary, 130 tertiary and sludge treatment. An overview of the WW treatment stages and its energy demand $131\left(\mathrm{kWh} / \mathrm{m}^{3}\right)$ is given in Figure 3. 


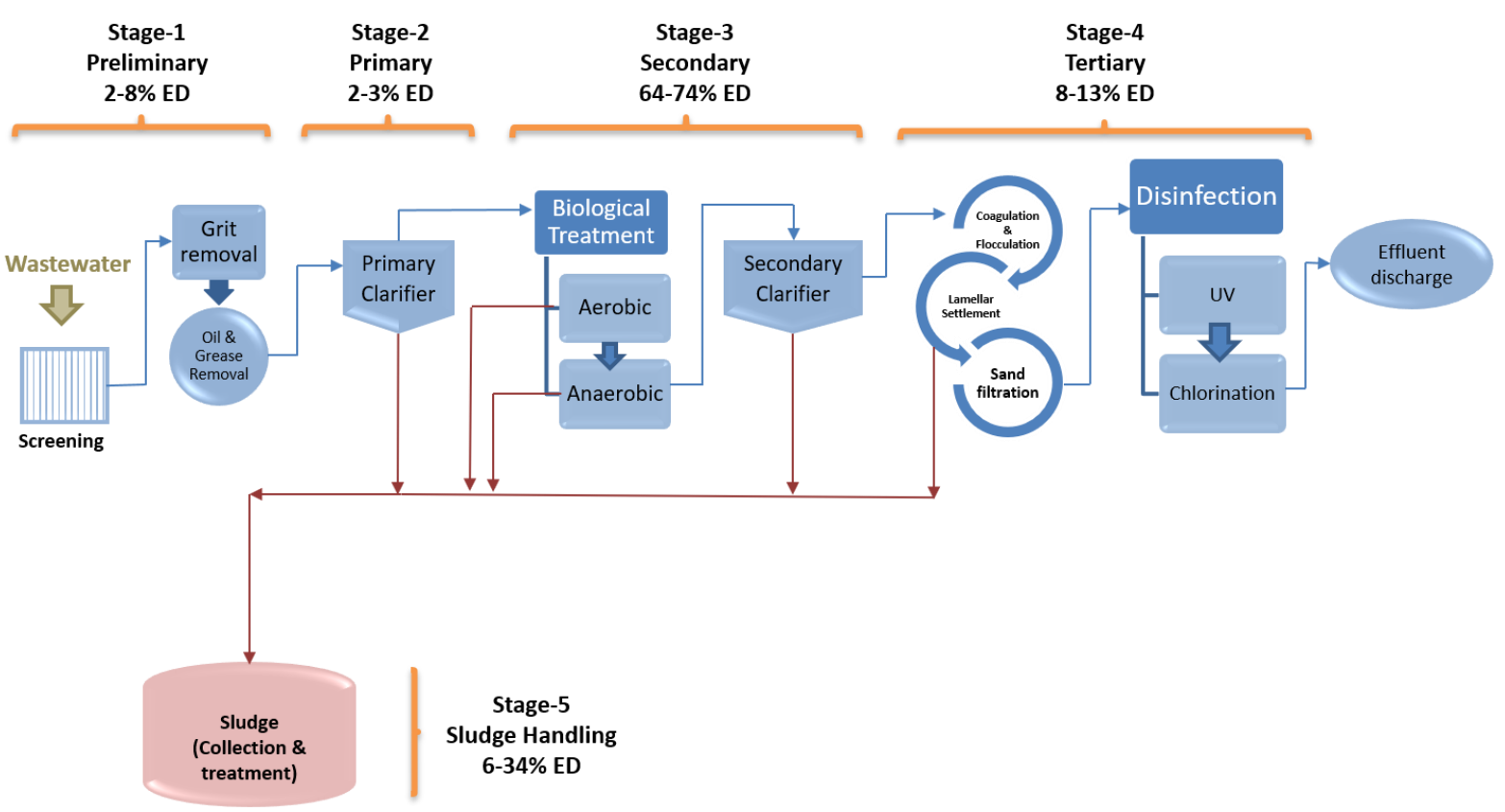

Figure 3: Wastewater treatment stages and its energy demand (ED)(Longo et al., 2016)

WW collected from the source primarily undergoes preliminary treatment, where WW is screened for the removal of the coarse and floatable solids like paper, plastics, rags, rubber, metals, fruit and vegetable waste. Following this, WW is transferred to grit removal chamber for the removal of gravel, sand and cinder to avoid any clogging in the pipelines and pumps (EPA Fact Sheet, 2013). Energy demand of the preliminary treatment ranges between 0.009$0.018 \mathrm{kWh} / \mathrm{m}^{3}$, which represents $2-8 \%$ of the total energy demand of the WW treatment process (Longo et al., 2016). Effluent from the preliminary treatment is then transferred to the primary clarifier/sedimentation tank, where suspended solids are separated by gravity in a circular tank with a mechanical scrapper for the removal of scum. Solids settled in this process are called primary sludge, which are collected in the hopper and sent for further treatment. About 50-70\% of total suspended solids (TSS) and $25-40 \%$ of the biochemical oxygen demand (BOD) are removed by this process. Efficiency of this process can further be increased by addition of the coagulants prior to the sedimentation process (Metcalf and Eddy, 2014). This stage of WW treatment demands for 2-3\% of the energy demand of the treatment (Longo et al., 2016). Following this, a secondary/biological WW treatment is applied for the removal of dissolved organic solids. Where, the aerobic or anaerobic bacteria degrades dissolved organic solids in WW. Aerobic WW treatment processes include activated sludge process, high-rated oxidation pond, oxidation ditch, carrousel, tapered aeration, step-aeration, contact stabilization, aeration 
pond, rotating biological contactors and trickling filters. Of these, activated sludge, trickling filters and aeration ponds are the most commonly used processes. The most used anaerobic treatment processes include up-flow anaerobic sludge blanket (UASB) and fluidized bed bioreactor (Boari, Mancini and Trulli, 1997). Membrane bioreactor is an efficient biological treatment process that can be operated in aerobic and anaerobic conditions (Yeh and Perito, 2011). Biological techniques such as anaerobic-oxic $(\mathrm{A} / \mathrm{O})$, anaerobic-anoxic-oxic $\left(\mathrm{A}^{2} \mathrm{O}\right)$, Bardenpho, Ludzack-Ettinger and modified Ludzack-Ettinger (MLE) are few of the biological nutrient removal techniques followed by the WWTPs (ENERWATER, 2018). Effluent from the secondary treatment is then transferred to the secondary clarifier/sedimentation tank, where microbes settled are partially recirculated to the biological treatment tank and rest is removed as secondary sludge (Nathanson and Ambulkar, 2019). Biological WW treatment with secondary clarification process forms third stage of the WW treatment. The efficiency of this stage ranges within $0.15-0.77 \mathrm{kWh} / \mathrm{m}^{3}$ based on the applied treatment technique (Longo et al., 2016). Effluent from secondary clarifier is then transferred to the tertiary treatment tank for the nutrient removal and disinfection. Chemical precipitation, adsorption, chemical oxidation, phostrip (Boari, Mancini and Trulli, 1997) and filtration are some of the physio-chemical nutrient techniques. Chlorination and UV disinfection techniques are the most used disinfection process. Ozonation is also a disinfection technique followed by some WWTPs (Longo et al., 2016). The type of the tertiary treatment applied varies with the level of nutrients and pathogen in the secondary effluent and the regulations of the respective geographic location. The energy demand of the tertiary treatment processes accounts for about 8-13\% (Longo et al., 2016). Finally, the sludge generated during different stages of WW treatment is collectively treated i.e., stabilized (aerobic or anaerobic), dewatered (mechanical or thermal) and disposed (land or water) (Hall, 1999) at an energy demand of $0.012-0.27 \mathrm{kWh} / \mathrm{m}^{3}$ (Longo et al., 2016).

\section{Energy reduction tools and strategies $\left(\mathbf{R}_{1}\right)$}

The energy demand of WWTPs varies from one plant to the other. Energy demand of the WWTP with nutrient recovery facility ranges between $0.5-2.0 \mathrm{kWh} / \mathrm{m}^{3}$, whereas for plants without nutrient removal facilities is lower than $0.5 \mathrm{kWh} / \mathrm{m}^{3}$ (Gude, 2015). From the energy data represented in Figure 4 (gathered from different literature), medium to large scale WWTPs are more likely to have nutrient recovery facilities. It is also shown that the energy demand of WWTPs increases with the increase in the level of the WW treatment (i.e., number of WW treatment stages). It is also evident from Figure 4 that the energy intensity per cubic meter of 
WW treated decreases with increase in the size of the WWTP, mainly due to the effects of economies of scale (PIER/EPRI, 2002).

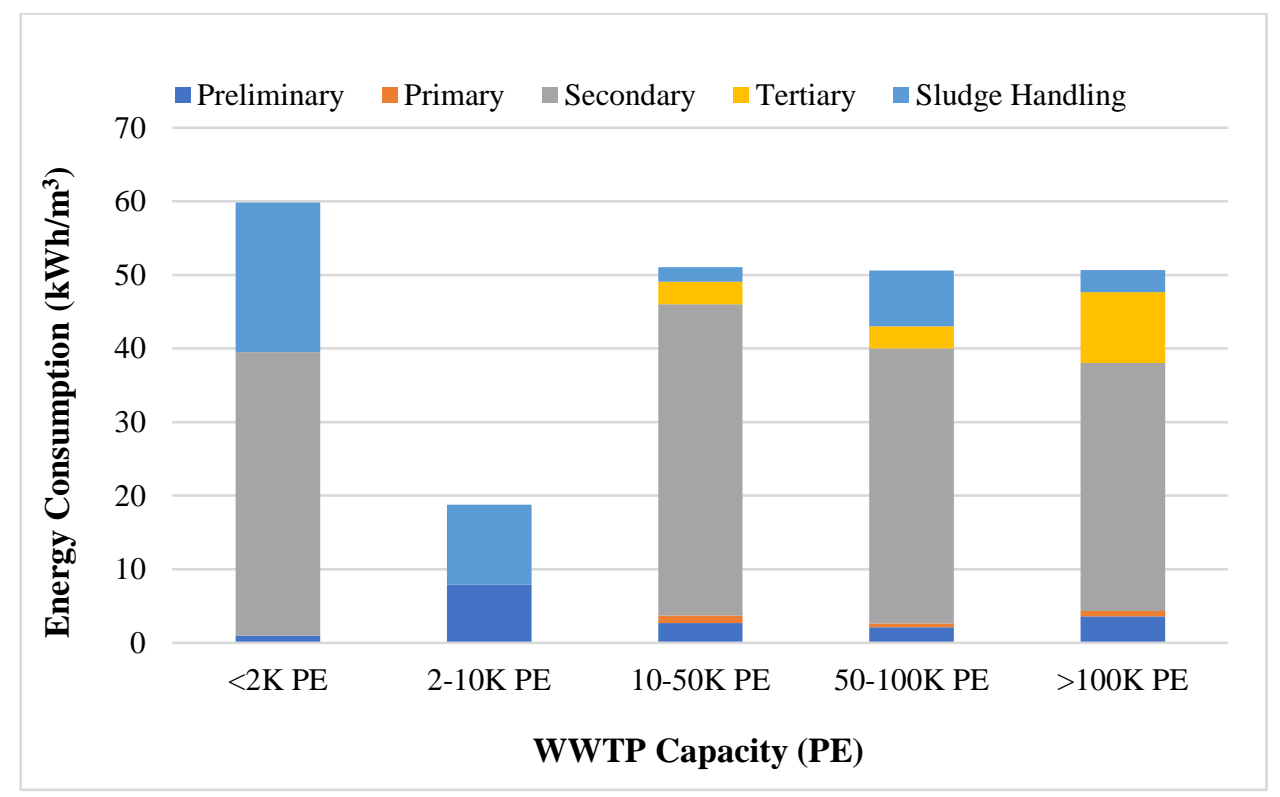

Figure 4: Average energy consumption of the WWTPs based on plants capacity and level of treatment (Longo et al., 2016)

One of the initial steps in assessing the energy demand of WWTPs and its carbon emissions is by energy auditing. Energy auditing helps in identifying the significant energy consumers (processes and equipment) of the WWTPs (Daw et al., 2012). According to some studies in literature, old or aging equipment is reported as inefficient, cost and energy intensive. Regular evaluation of equipment (electro-mechanic devices) condition, performance and lifespan helps in the repair and replacement. Preventative maintenance practices are the most suggestive evaluation measures for an appropriate maintenance of the equipment (Hernández-Chover et al., 2020). Around 5\% of the energy can be saved by regular maintenance of the electromechanic devices and repair and replacement of the inefficient systems.

The modelling tools belonging to the R1 category can be classified as: i) energy auditing and benchmarking tools, ii) energy management tools, aimed at improving the energy efficiency of specific process/equipment and iii) decision support tools. Some tools are specific for the facility for which they have been developed while others can be more widely applied.

The European project "ENERWATER" developed one of the most comprehensive energy benchmarking model. Energy benchmarking can be seen as the first step to understand how energy is used in the WWTPs. However, energy benchmarking of WWTPs is a difficult task, 
as there is no standard key performance indicator (KPI) to analyse the energy demand of different wastewater facilities, furthermore since the energy demand is strongly influenced by the characteristics of the wastewater treated and the process used, the challenge is to identify common benchmarking values. "ENERWATER" attempted to address such challenges by developing an MS-Excel tool that analyses the energy consumption of the WWTPs based on the size of the plant, flowrate and quality of the influent WW and type of the WW treatment techniques applied. According to this study, $\mathrm{kWh}$ per People Equivalent (PE) per year $\left(\mathrm{kWh} / \mathrm{PE}^{*} \mathrm{y}\right)$ and $\mathrm{kWh}$ of Chemical Oxygen Demand (COD) removed (kWh/kg COD) are the most reliable water-energy indexes over $\mathrm{kWh}$ per cubic meter of treated $\mathrm{WW}\left(\mathrm{kWh} / \mathrm{m}^{3}\right)$. The energy benchmarking in this study was developed using different KPIs based on pollutant load such as COD, total nitrogen, total phosphorus and total suspended solids aligning with the purpose of treatment stages. Average influent flow rate and characteristics, equipment inventory with nominal power load and number of working hours are the major inputs of this tool. The output is the energy breakdown of the treatment processes and equipment. This tool is freely available for any manager of a WWTP who may get guidance on how to improve the energy on site (Longo et al., 2019). Similarly, Sabia et al (2020) developed an energy benchmark model to evaluate WWTP energy performance.

"Energy Online System (EOS)" is an example of energy auditing and benchmarking tool that can be used by researchers, local and regional water facilities. The methodology was developed by Torregrossa et al (2018) at Luxembourg Institute of Science and Technology (LIST). The tool provides a daily benchmark analysis under limited database conditions. Different from ENERWATER the tool is completely dependent on the data received from sensors installed at the WW facility. The data recorded by sensors is collected, analysed and the outputs are represented as daily Key Performance Indicators (KPIs). Information gathered can be used to optimize the pumps, blowers and the anaerobic digesters for the sludge treatment. Support vector regression, Fuzzy logic (FL), Artificial neural network (ANN) and Random forest (RF) are the optimization techniques (machine learning methods) applied for the development of this tool. Similarly, Ramli and Hamid (2019) developed a prediction model to optimize the WWTP equipment and machines using machine learning method ANN. The main purpose of this study was to minimize the energy demand of the WWTP by predicting the energy demand one month in advanced. The final goal was to make wastewater treatment plants affordable for underdeveloped regions. WWTP in Peninsular Malaysia configured with aerated lagoons and 
Conventional Activated Sludge (CAS) was considered for this study. Energy savings of $2.23 \%$ were predicted by this model.

Looking at energy auditing tools developed for specific wastewater facilities, Long and Cudney (2012) developed a multilinear regression model to analyse the key operating parameters influencing the energy consumption of Rolla Missouri Southeast WWTP and to identify the most energy demanding processes. The energy was accounted on the basis of an average influent flowrate and pollutant load (Biological Oxygen Demand, BOD, and suspended solids). Based on the treatment and building efficiencies, an energy rating of the plant was developed. The highest energy demanding equipment identified was the blowers in oxidation ditch, pumps in trickling filter, and clarifier. This study also highlighted a high GHG emissions from old equipment used at the plant and suggested an upgrade of such technologies.

Another example of management tool was developed by Holanda et al. (2007). The aim of this study was to improve the activated sludge process for an efficient removal of pollutants especially nitrogen, reduce the energy consumption and the sludge generation. The modelling tool is aimed at optimally manage the Altering Activated Sludge (AAS) process. In the work aerobic and anoxic (AA) treatment was initiated in a single tank to optimize energy consumption and reduce sludge generation. Genetic algorithm (GA) is the optimization technique followed to develop this biological nitrogen removal (BNR) model. Maximum pollutant removal efficiency of the process was evaluated by the effluent quality (EQ) index. According to this study, the influent quality plays a vital role in the selection of the aeration time, number of cycles and energy consumption of the process. It also states that the efficiency of the treatment increases by increasing the number of aeration cycles (up to 26 cycles) and decreases with the increase in aeration time of each cycle (i.e., above 20 minutes). Application of this model and process is suggested to reduce the pollutant load and energy consumption by about $10 \%$ to the conventional process. Alongside its benefit, this model has low computational intensity, which can be minimized by the identification of the initial pollutant load of the WW and appropriate selection of optimization parameters (Holanda et al., 2007).

A mathematical model was developed by Novak and Horvat (2012) for improving the treatment and energy efficiency of the aerobic WW treatment process. This model involves optimizing the oxygen electrode type (oxygen diffusion layers around the cathode) and position (within bioreactor and in outlet shaft) in an aerobic bioreactor. The biological process modelling was based on the ASM-3_2N model i.e., a modified activated sludge model number 3 with two- 
step nitrification-denitrification process. Optimization of this model was based on cost module i.e., the total functional cost of the WWT that varies with the volume of the bioreactor. It is a MATLAB launch code for activated sludge model with three benchmark input files (third modified version of original model) developed by researchers at the University of Florence. According to this study, the electrode with (1) an outer membrane layer and (2) electrolytic gel between membrane layer and cathode are highly efficient for the treatment of WW due to its reaction mechanism. It also states that the increased number of oxic/anoxic cycles with low cycling time for oxygen electrode placed within bioreactor is more efficient over the oxygen electrode placed in an outlet shaft. The WW parameters such as Dissolved Oxygen (DO), COD, BOD for 5 days (BOD5), Suspended solids, nitrates, nitrites and ammonia were analysed to assess the efficiency of the treatment process.

Machine Learning Techniques represent the most innovative approach to reduce the energy demand of the WWTPs, which was discussed earlier in this section for WW treatment equipment's energy optimization. Similarly, other researchers like Cao and Yang (2020) developed a model using Online Sequential Extreme Learning Machine (OS-LEM). OS-LEM is a modified neural network. This model is based on Benchmark Simulation Model No.1 (BSM1), which consists of two anoxic and three anaerobic zones that are designed from Activated sludge model no.1 (ASM1). The main purpose of this model is to improve the supply of dissolved oxygen (DO) to the treatment zones considering various factors such as influent and effluent WW quality and weather. Around $40 \%$ of the energy savings is suggested by controlled DO supply to the aerobic/anoxic treatment tanks (Cao and Yang, 2020).

Molinos-Senante et al (2015) assessed (by modelling) the $\mathrm{CO}_{2}$ shadow price that represents the economic value of the externalities linked to the energy consumed by WWTPs. The model uses directional distance functions. Directional distance function is a generalised form of Shephard's output distance function that allows elaboration of the desired output and curtails the undesired ones. General Algebraic Modelling Software (GAMS) in combination with CPLEX solver was used in addressing the problem (linear) and estimating the directional distance functional parameters. The study involves 25 WWTPs in Spain with capacity ranging between $0.5-1.5 \mathrm{M} \mathrm{m}^{3} /$ year. Energy, staff and other costs are the main inputs of this analysis to return the desired outputs like volume of the treated WW and the quantity of the WW pollutants removed (like COD, suspended solids, nitrogen and phosphorus). According to this study, the $\mathrm{CO}_{2}$ shadow price of WWTPs ranges between 5 to $35 \%$ the price of the treated water. The study also states that large WWTPs and plants with the tertiary treatment process are more 
likely to have high $\mathrm{CO}_{2}$ shadow price. Sewage sludge treatment was also suggested as the most influential factor affecting the value of $\mathrm{CO}_{2}$ shadow pricing and concluded that anaerobic treatment is the better option over other techniques due to its energy recovery potential.

Another example of decision support tool is TIAM-FR developed by researchers at the MINES Paris Tech Centre for Applied Mathematics. The model aimed at optimising the future energy demand of the water sector in region under severe water scarcity like Middle East countries (Arabian Peninsula, Caucasus, Iran and other regions near East) (Dubreuil et al., 2013). The TIAM-FR is a TIMES integrated water allocation assessment model that was developed based on resulted efficiencies of the three simulation studies (1) only water, (2) only energy module and (3) combination of water and energy module. Optimization of the developed simulation model was based on the total discounted cost of the energy system, which includes investment cost, fixed cost, variable costs of the processes and commodities, taxes and subsidies, elastic demand adjustment cost and salvage. Water allocation technologies, water reuse (nonconventional) and efficient irrigation technologies were analysed under the water module of the model. Whereas, energy demand for water abstraction, treatment and supply to the endusers such as rainfed agriculture, irrigation, municipal and industrial sectors was considered under the energy module. The time frame considered for this study is from 2005 to 2050 with a time series of 10 years. The energy intensity of the water use, such as technical strategies and available water management options were suggested as the best analysers of the Water-Energy nexus tool (which also includes WW) (Dubreuil et al., 2013).

Padrón-Páez et al (2020) conducted a case study on municipal WWTPs in Mexico to guide policy makers in designing new polices for future (new) plants. Different optimization methods like Mixed-integer non-linear programming (MINLP), Lexicographic and $\epsilon$ constraint methods were used in the analysing various factors influencing the cost and energy demand of the treatment plants. Finally, the results obtained from different techniques were compared using Technique for order of preference by similarity to ideal solution (TOPSIS) method for the best solution. According to this, the energy and total cost of the plant can be reduced by $20 \%$ and $93 \%$ respectively by appropriate selection of treatment techniques and optimization of flowrate and pollutant load for treatment.

Table 1 gives an overview of the different modelling studies on wastewater treatment energy optimization discussed earlier in this section.

\section{Table 1. Overview of Wastewater treatment energy optimization}




\begin{tabular}{|c|c|c|c|c|}
\hline Reference & $\begin{array}{l}\text { Wastewater } \\
\text { treatment process } \\
\text { considered }\end{array}$ & Model goal & $\begin{array}{l}\text { Energy } \\
\text { reduction/savings } \\
\text { achievable }\end{array}$ & Study location \\
\hline Longo et al., 2019 & Entire WW facility & $\begin{array}{l}\text { Energy } \\
\text { benchmarking }\end{array}$ & - & - \\
\hline $\begin{array}{l}\text { Long and Cudney, } \\
2012\end{array}$ & Not Specified & $\begin{array}{l}\text { Minimise the } \\
\text { consumption of } \\
\text { pumps, motors and } \\
\text { other electro- } \\
\text { mechanic devices }\end{array}$ & $10-20 \%$ & $\begin{array}{l}\text { Rolla, Missouri } \\
\text { Southeast } \\
\text { USA }\end{array}$ \\
\hline $\begin{array}{l}\text { Torregrossa et al., } \\
2018\end{array}$ & $\begin{array}{l}\text { Aerobic treatment } \\
\text { and anaerobic } \\
\text { sludge digestion }\end{array}$ & $\begin{array}{l}\text { Minimise the } \\
\text { consumption of } \\
\text { pumps, blowers } \\
\text { and AD }\end{array}$ & $50-80 \%$ & Europe \\
\hline $\begin{array}{l}\text { Ramli and Hamid, } \\
2019\end{array}$ & $\begin{array}{l}\text { Aerated lagoons } \\
\text { and CAS }\end{array}$ & $\begin{array}{l}\text { Minimizing the } \\
\text { energy } \\
\text { consumption of } \\
\text { pumps and blowers }\end{array}$ & $2.23 \%$ & $\begin{array}{l}\text { WWTP } \\
\text { Peninsular } \\
\text { Malaysia }\end{array}$ \\
\hline Fikar et al., 2005 & $\begin{array}{l}\text { Activated sludge } \\
\text { process }\end{array}$ & $\begin{array}{l}\text { Minimise the } \\
\text { energy demand of } \\
\text { the activated } \\
\text { sludge process }\end{array}$ & $20-30 \%$ & $\begin{array}{l}\text { Small scale WWTP } \\
\text { in France }\end{array}$ \\
\hline $\begin{array}{l}\text { Holanda et al., } \\
2007\end{array}$ & $\begin{array}{l}\text { Altering activated } \\
\text { sludge/Biological } \\
\text { nutrient removal }\end{array}$ & $\begin{array}{l}\text { Minimise the } \\
\text { number and time of } \\
\text { aeration cycles }\end{array}$ & $10 \%$ & - \\
\hline $\begin{array}{l}\text { Novak and } \\
\text { Horvat., 2012 }\end{array}$ & $\begin{array}{l}\text { Activated sludge } \\
\text { process }\end{array}$ & $\begin{array}{l}\text { Minimise the } \\
\text { oxygen used }\end{array}$ & $20-25 \%$ & WWTP in Croatia \\
\hline $\begin{array}{l}\text { Molinos-Senante } \\
\text { et al., } 2015\end{array}$ & Entire WW facility & $\begin{array}{l}\text { Minimise the } \mathrm{CO} 2 \\
\text { shadow prices } \\
\text { linked to the } \\
\text { energy used by } 25 \\
\text { WWTPs }\end{array}$ & Up to $50 \%$ & - \\
\hline $\begin{array}{l}\text { Dubreuil et al., } \\
2013\end{array}$ & Not specified & $\begin{array}{l}\text { Minimise the } \\
\text { forecasted energy } \\
\text { demand of the } \\
\text { water sector } \\
\text { (considering WW } \\
\text { facilties) }\end{array}$ & $5-30 \%$ & $\begin{array}{l}\text { Middle } \\
\text { countries }\end{array}$ \\
\hline $\begin{array}{l}\text { Cao and Yang, } \\
2020\end{array}$ & $\begin{array}{l}\text { Anoxic and aerobic } \\
\text { treatment (ASM1) }\end{array}$ & $\begin{array}{l}\text { Controlled DO } \\
\text { supply through cost } \\
\text { minimization }\end{array}$ & Up to $40 \%$ & WWTP in China \\
\hline $\begin{array}{l}\text { Padrón-Páez et al., } \\
2020\end{array}$ & Not specified & $\begin{array}{l}\text { Minimizing the } \\
\text { total cost and } \\
\text { energy } \\
\text { consumption of the } \\
\text { WWTPs for } \\
\text { designing } \\
\text { sustainable } \\
\text { WWTPs }\end{array}$ & Up to $20.2 \%$ & $\begin{array}{l}\text { Municipal WWTP } \\
\text { in Mexico }\end{array}$ \\
\hline
\end{tabular}

336 The studies developed so far show that the energy demand of WWTPs depend on several 337 factors: the influent flowrate and pollution load, size of the WWTP, type of the treatment 338 technologies employed and level of the WW treatment applied. COD, suspended solids, 339 nitrogen and phosphorus are the most commonly considered load parameter that influence the 
energy consumption of the plant and the treatment efficiency. Regular evaluation of the influent and effluent operational parameters, that are highly influenced by seasonal variations, time of the day and other characteristics help in controlling the operations of the plant (Daw et al., 2012). Pumps used at the WWTPs are reported as the most energy consuming equipment in the literature, whose optimization can save 5-30\% of the total energy demand (Panepinto et al., 2016). Timely identification of infiltration breaks and leaks in the pipes enables its possible repair or replacement along with energy and financial saving. Coming to the treatment processes, the aerobic treatment is the most widely used secondary treatment at high energy input. There is a good scope of energy saving in this process, estimated at about $20-50 \%$ (Georges et al., 2009) by installation of automatic control system for aeration and installation of energy efficient aerating devices. Installation of the automatic system for monitoring the equipment, treatment processes and influent and effluent quality can further improve the energy efficiency of the WWTP and increases flexibility in supervision of the plant. Further, replacement of the aerobic treatment (where possible) with anaerobic reduces the $\mathrm{CO}_{2}$ emissions up to $60 \%$ (Keller and Hartley, 2003). Next to the aerobic treatment, WWTPs with tertiary treatment and sludge treatment are also suggested to increase the energy demand of the plant, which are purely based on the treatment techniques employed by the plant. Smart selection of the technology for sludge treatment can help the WWTPs to reduce the energy demand and, as we will discuss in the following section, to produce energy.

\section{Energy recovery tools and technologies $\left(\mathbf{R}_{2}\right)$}

Although the current study focuses on energy optimization of the WWTPs, effluent quality is of primary significance to avoid any negative impacts on our health and environment. In some cases, the most efficient WW treatment remains a high energy intensive process even after energy optimization. Such WWTPs still have a room of opportunity for reducing its dependency on grid electricity by energy recovery from WW or, as discussed in section 5 by integrating local available renewable sources. Wastewater is a good carrier of energy and nutrients (van Loosdrecht et al., 2014) and defined by some researchers as "Water Resource Recovery Facilities (WRRF)" (Bala, 1997). The economic value of the resources such as water, nutrients (Nitrogen, Phosphorus and Potassium), energy (biogas) and biofertilizer (treated nutrient rich sludge) recovered from the WW is \$0.47/unit WW (Verstracte et al., 2009). As mentioned above, WW contains an organic energy of about 9-10 times greater than the energy used for its treatment (Shizas and Bagley, 2004) and 3 times more thermal energy (Dürrenmatt 
and Wanner, 2014). The major source of organic energy at WWTPs is the sludge generated by the WW treatment. Sludge is a heterogeneous mixture of undigested and partially digested organic matter, fat, oil and grease (FOG), micro-organisms, inorganic material and moisture (water) (Tyagi and Lo, 2013). Landfill, agriculture use, ocean disposal and incineration have been the commonly used sludge management techniques for many years. Few of these techniques are banned in some regions and few others are limited in application due to their adverse effects on the environment, marine ecosystem, ground water resources and in turn on human health (Frišták et al., 2018). The anaerobic sludge treatment can serve as an economical and ecologically efficient process due to biogas production (World Energy Outlook 2019). Anaerobic digestion (AD) is a well-known technology that is highly efficient in extracting the organic energy from sludge (Hao et al., 2015). Anaerobic digestion is a degradation of the organic matter by diverse micro-organisms in the absence of oxygen to produce biogas. There are four stages in the AD process: (i) hydrolysis- breakdown of carbohydrates, proteins and lipids to simpler molecules i.e., sugars, amino acids and long chain fatty acids, (ii) acidogenesis- production of acids (acetic, propionic and butyric acids) and alcohols (ethanol and lactate) from simple molecules formed in hydrolysis, (iii) acetogenesis- conversion of acids and alcohols formed in acidogenesis to acetate, hydrogen and carbon dioxide and (iv) methanogenesis- production of biogas $\left(\mathrm{CH}_{4}, \mathrm{CO}_{2}, \mathrm{H}_{2}\right.$ and other gases) and nutrient rich digestate (Meegoda et al., 2018). According to the IPCC (2007), carbon emissions from the combustion of the biogas are considered as short-cycle and are not accounted under the GHG emissions from the wastewater treatment facilities. Although, anaerobic digestion (AD) increases the rate of sludge production, its $\mathrm{CO}_{2}$ emissions are five times less than the other sludge treatment processes (especially aerobic) (Mayhew and Stephenson, 1997). Utilizing the digestate from anaerobic digester as a biofertilizer reduces $-7.04 \times 10^{-2} \mathrm{~kg} \mathrm{CO}_{2}$ of global warming caused due to the chemical fertilizer manufacturing (Pasqualino et al., 2009).

The models belonging to $\mathrm{R}_{2}$ group are aimed at assessing and maximising the energy production from wastewater. Majority of models have been developed for the biogas production from sludge, being the main source of energy production from wastewater. Additional models have looked at the recovery of thermal energy and hydrogen production from wastewater.

Considering the energy and environmental benefits of sludge, two municipal WWTPs in Austria have successfully proved to be energy positive by efficient utilization of energy recovered from sludge. One of these plants are Wolfgangsee-Ischl WWTP in Austria. The 
positive energy balance of this WWTPs was reported due to the long life of the plant (in operation since mid-1980s) along with optimized mechanical devices and aeration process at the plant. Further to this, this plant generated $7 \%$ surplus electricity from biogas generated from anaerobic digestion sludge. Whereas the other municipal WWTPs "Strass" was reported with an average surplus electricity generation of $6.3 \%$ from sludge anaerobic digestion during 20052007. This value was further increased to $80 \%$ by co-digestion of sludge with kitchen waste in 2008. Most of the WWTP anaerobic digesters are designed oversize, whose extra space can be efficiently utilized by co-digestion with other organic wastes like kitchen waste, restaurant waste, animal waste etc. This not only helps in improving the quantity of biogas produced but also the quality i.e., increases methane concentration in biogas. The produced biogas can efficiently be utilized at the site for energy generation or can be supplied to grid or neighbourhood to reduces its wastage and emission into the environment (World Energy Outlook 2019). The digestate generated from the two Austrian WWTPs was dewatered and used in land application (as fertilizer). Despite the surplus energy generation, these two WWTPs rely on the grid electricity for their peak electricity supply (Nowak et al., 2015).

Another group of researchers Puchongkawarin et al (2015) developed a methodology for resource recovery and energy generation from WW by superstructure modelling. The optimization of the model is based on maximizing the net present value (NPV) of the system, for which the cost data was derived from CAPDETWORKS ${ }^{\mathrm{TM}}$ costing software. A WW simulator, GAP- $\mathrm{X}^{\mathrm{TM}}$ was used to predict the efficiency of different treatment integrations. To demonstrate the efficiency of this model, a case study was conducted on wine distillery WW. The superstructure model of the case study involved two biological treatment units i.e., upflow anaerobic sludge blanket reactor (UASB) and single membrane bioreactor (SMBR), two filtration units i.e., sand filter and membrane unit and two nutrient recovery units i.e., struvite crystallizer and zeolite adsorption as a part of the investigation. Three scenarios of integrated treatment and resource recovery were considered in this study. In the first scenario, $60 \%$ of the WW was treated by UASB and $40 \%$ was transferred directly to the recovery unit. In the second scenario, major of the WW was treated by UASB and very little volume was transported to the extraction unit directly without any treatment and in third scenario WW was initially treated by UASB then followed by ion exchange. Among these, the first scenario was found efficient over other two scenarios due to better treatment of WW at low capital expenditure and high revenue from energy and nutrient recovery. Further, the authors recommended broad range of 
technological exploration for this methodology to be considered as a decision support tool for energy and nutrient recover by WWTPs.

Similarly, Sun et al (2020) developed a composite model to assess the sustainability and resilience of the WW management through four alternative approaches by Analytical hierarchy method. These approaches include (i) centralised WW treatment by activated sludge (AS) and MBR, (ii) decentralised approach of UASB and trickling filter (TF), and (iii) centraliseddecentralised hybrid system (based on the type of WW). A decentralised and hybrid approach was resulted in higher sustainability and resilience over others (centralised CAS and MBR) with 7-17\% higher trade-off cost and energy and nutrient recovery. Alternatively, decentralised WW treatment was suggested as the best approach, except for the regions with the increased risk of eutrophication. Likewise, Sarpong et al (2019) assessed energy self-sufficiency of the small scale WWTPs under different combinations of WW treatment (including advanced treatment) and energy recovery technologies . Combination of anammox process followed by activated sludge process and anaerobic digestion of sludge was reported with higher energy reduction/recovery (115\%). This was further increased (above $225 \%$ ) by co-digestion of sludge with FOG. According to this study, selection of an appropriate treatment technique and codigestion of sludge can make small scale WWTPs energy self-sufficient.

Soda et al (2010) evaluated energy recovery potential of sludge by AD along with estimation of energy demand and GHG emissions of a sewage sludge treatment plant (SSTP) in Osaka (Japan) by a modelling approach. Energy demand of different processes such as sludge thickening, sludge dewatering, anaerobic digestion, sludge incineration and melting applied at the plant were accounted. Different treatment configuration with AD energy recovery was formed to identify economic and environment friendly approach. Treatment configuration with high loading rate of $\mathrm{AD}$ was found economically feasible but landfilling of partially digested sludge from $\mathrm{AD}$ had high risk of $\mathrm{CH}_{4}$ and $\mathrm{N}_{2} \mathrm{O}$ release into the environment. To address this, two solutions i.e., (1) environment friendly- application of incineration and melting to the digested sludge to reduce the risk of environmental emissions, although at high energy demand or (2) economical- disposal of digested sludge to landfills for high energy recovery (by landfill gas collection) were suggested by the authors. Incineration is a thermochemical process majorly employed for volume reduction of waste and destruction of the harmful substances in the sludge at very high temperature prior its disposal (Syed-Hassan et al., 2017). It is a heavily regulated and socially opposed issue to incinerate the sludge due to its emissions into the atmosphere such as mercury, dioxins, ash etc. The ash produced during the process of 
incineration are to be handles as the hazardous waste or are to be landfilled to avoid its impact on the environment (Palme et al., 2005). Hence, this technology is applicable at facilities with limited disposal space and lower odour tolerance plants such as municipalities with high population (Werther and Ogada, 1999). In some cases, heat generated by incineration of sludge is recovered for its further application as thermal energy. For example, in heating boilers for steam generation at steam power plants (Cui et al., 2006). A group of researchers in USA analysed the status of energy recovery of sludge by anaerobic digestion and incineration techniques. According to this study, WWTPs above 19,000 m3/day are suitable for energy recovery by $\mathrm{AD}$. It also reported that an electricity generated from biogas and biosolid incineration can reduce the energy dependency of the WWTPs by $2.1-26 \%$ and $2.5-57 \%$ respectively in Texas city. Whereas, combination of $\mathrm{AD}$ and incineration can reduce the energy dependency between $4.7-83 \%$ in Texas city and 2.6-27\% in whole USA (Stillwell et al., 2010). This study also reported that some of the WWTPs in USA does not make efficient use of the biogas produced and flare it into the atmosphere. This has a risk of increasing GHGs in the environment. Collection of this biogas and efficient use or treatment of this gas (less impact gas) before releasing into the environment is important. An integrated waste management tool "Solid waste and WW management system (SWW)" was developed by Maalouf and El-Fadel (2020) to minimize the carbon emissions and cost of the system. Due to integrated waste management system, the biological WW treatment such as aerobic (CAS) and anaerobic (lagoons and septic tank) and sludge management are the significant processes considered under WW management. Here, the energy was recovered using AD and incineration in combination with MSW. Along with energy recovery, sludge disposal methods like composting and controlled landfilling were reported to reduce the carbon emissions of the integrated system by about $90 \%$ by smart selection of the technologies/treatment process. Although incineration seems an interesting technique for energy recovery but incurs additional cost $(10 \%$ of the total cost of the system). This tool is highly suitable for the regions with integrated waste management systems (solid and WW treatment together).

Some of the models developed in literature consider the energy recovery in combination with nutrient recovery. An example is given by an excel based simulation model was developed by Khiewwijit et al (2015) for future Dutch WWTPs. The model was built based on data collected from 29 Dutch WWTPs, data available in the literature and lab scale experiments. The treatment technologies considered for this design are: bio-flocculation, $\mathrm{AD}$, phosphorus recovery through micro-algae, chemical precipitation and biological process, annamox process 
for nitrogen recovery and conventional activated sludge. The design of this model consists of five steps, first is setting up a key performance indicator, second is the selection of efficient treatment and resource recovery technologies, third is to integrate all the selected technologies, fourth is to perform a steady-state simulation for energy balance and finally conducting sensitivity analysis of the developed model. Different configuration of the energy recovery processes considered were analysed. Of which, three combinations i.e., Bio-flocculation with $\mathrm{AD}$, Annamox process (only) and chemical precipitation and biological phosphorus recovery was reported to be the most efficient with $0.24 \mathrm{kWh} / \mathrm{m}^{3}$ net electricity generation and $35 \%$ reduction in the carbon emissions. The organic load was reported as the rate limiting factor in the energy consumption and generation.

As abovementioned, WW is good carrier of thermal energy, it is a good opportunity for the WWTPs to recover that energy and use on site, the key aspect is to identify a heat load on site or nearby, since WWTPs consume mainly electricity. Water source heat pumps (WSHP) are the most used technology for heat recovery from WW. Net electricity equivalence of heat recovered from WW is $0.26 \mathrm{kWh}$ per $\mathrm{m}^{3}$ effluent cooled by $1^{\circ} \mathrm{C}$ (Dürrenmatt and Wanner, 2014). Due to lower electrical conversion efficiency of thermal energy recovered by WSHP, heat generated can be used at WWTPs towards biological treatment process like AD, sludge drying, heating and cooling of WWTP. The surplus thermal energy recovered can also be supplied to the neighbourhood buildings (Gude, 2015). A decentralised approach of thermal energy recovery from sewer WW and electricity from organic kitchen waste of small residential community in USA was reported by Yang and Shen (2014). The main purpose of this study was to reduce waste at source. Electricity of $2.98 \times 10^{5} \mathrm{kWh}$, which is equivalent to $8 \%$ of the total electricity demand of the community was generated from anaerobic digestion of kitchen waste. Thermal energy required for the waste digestion was recovered from the sewer WW, which is equivalent to $1.5 \times 10^{12} \mathrm{~J}$ of useful heat per year. To maximize the energy and nutrient recovery from municipal WWTPs in Austria, a simulation model was developed using Process Network Synthesis (PNS) method (Kretschmer et al., 2016). PNS is a bipartite graph method used in structuring the optimization problem. According to one of the case studies on this model, electric energy from anaerobic digestion of sludge and thermal energy recovery from WW using heat pumps is higher than the plant demand. Supply of the surplus electricity to the neighbouring buildings or society was suggested as an alternative and revenue making option. A simple system management to decarbonize the domestic WW from its generation (household) to treatment and discharge (into water bodies) was studied by Larsen (2015). 
Efficiency of different aerobic treatment processes (like conventional, annamox and mainstream), electric energy recovery potential of sludge and thermal energy recovery potential of household and sewer WW were analysed for low carbon options. As per the analysis, heat recovery from the household WW (less heat dissipation) and WW treatment by annamox process were found energy efficient and environment friendly. Another study evaluated the energy generation potential of the dewatered sludge at Balingian and Mannheim WWTPs in Germany by gasification and combustion (Yang et al., 2016). Gasification is a thermochemical process that transforms organic matter in sludge to syngas $\left(\mathrm{CO}_{2}\right.$ and $\left.\mathrm{H}_{2}\right)$ in the presence of gasifying agents (e.g. controlled amount of oxygen, air, $\mathrm{CO}_{2}$ ) at high temperature $\left(>700^{\circ} \mathrm{C}\right)$ (Situmorang et al., 2020). Heat generated by combustion of syngas or heat released from cooling of syngas was used as a source of heat in drying sludge for gasification at these WWTPs. Electricity potential of $24-28 \%$ of the total plant demand was estimated from the combustion of syngas. The moisture content and equivalence ratio of $25 \%$ and 2.3 , respectively, were reported as the optimum conditions of sludge gasification. The equivalence ratio is a ratio of stoichiometric air-fuel mass ratio to actual air-fuel mass ratio.

Simultaneous, WW treatment and electricity generation were demonstrated by Subha et al (2019) through a mathematical modelling (Monod Kinetics) of Up-flow anaerobic microbial fuel cell (UAMFC) at lab scale. It is an integrated process of UASB and Single cell microbial fuel cell (SCMFC). The UAMFC consists of an anode covered with biofilm (growth of microorganisms on surface of solids) that degrade the organic matter present in the WW and produces electrons and hydrogen ions. These electrons from anode chamber travels to cathode through an external circuit to produce an alternative current (AC from DC current) (Al-Megren, 2009). The anode was separated from cathode by a proton exchange membrane (Nafion 117). WW (Chocolateries manufacturing) for treatment and electricity generation was supplied to the anode chamber through a WW holder at the bottom of the anode. The maximum power density of $98 \mathrm{~mW} / \mathrm{m} 2$ and $104.9 \mathrm{~mW} / \mathrm{m} 2$ was observed at an optimum HRT and OLR of $15 \mathrm{~h}$ and $0.8 \mathrm{~g} / \mathrm{L}$ COD respectively. An overall COD reduction of $70 \%$ was reported by UAMFC. Similarly, another group of researchers in USA have evaluated the economic feasibility of the MFC in treatment of the food processing WW for its reuse in irrigation. According to this study, although MFC seems to be highly expensive, it can be ideal for (i) drought/arid regions, where the cost of water is high and (ii) regions with high electricity prices. Preliminary research conducted by these researchers also states that the replacement of the conventional aerobic 
568 system with MFC can treat the WW at $9 \%$ of the total cost of the aerobic system. Further, 569 techno-economic feasible study is required for scaling up of this technology.

570 An overview of different modelling studies whose main aim is the WW energy recovery is 571 given in Table 2.

572 Table 2: Overview of the energy recovery and WW treatment process energy optimization models

\begin{tabular}{|c|c|c|c|c|c|}
\hline Reference & $\begin{array}{l}\text { WW treatment } \\
\text { technique }\end{array}$ & $\begin{array}{l}\text { Energy } \\
\text { recovery } \\
\text { technology }\end{array}$ & $\begin{array}{l}\text { Energy } \\
\text { optimization } \\
\text { goal }\end{array}$ & $\begin{array}{l}\text { Energy } \\
\text { generation }\end{array}$ & $\begin{array}{l}\text { Study } \\
\text { location }\end{array}$ \\
\hline $\begin{array}{l}\text { Nowak et al., } \\
2015\end{array}$ & $\begin{array}{l}\text { Aerobic } \\
\text { treatment } \\
\text { Anaerobic } \\
\text { treatment }\end{array}$ & $\mathrm{AD}$ & $\begin{array}{l}\text { Pump and } \\
\text { blowers; } \\
\text { overall AD } \\
\text { process }\end{array}$ & $100 \%$ & $\begin{array}{l}\text { WWTPs } \\
\text { Austria }\end{array}$ \\
\hline $\begin{array}{l}\text { Khiewwijit et al., } \\
2015\end{array}$ & $\begin{array}{l}\text { Bio-flocculation, } \\
\text { Activated sludge } \\
\text { process, Chemical } \\
\text { precipitation } \\
\text { Annamox }\end{array}$ & $\begin{array}{l}\text { AD \& Heat } \\
\text { pump (HP) }\end{array}$ & $\begin{array}{l}\text { WW } \\
\text { treatment, } \\
\text { AD and HP }\end{array}$ & Up to $50 \%$ & $\begin{array}{l}\text { WWTPs in } \\
\text { Netherlands }\end{array}$ \\
\hline $\begin{array}{l}\text { Puchongkawarin } \\
\text { et al., } 2015\end{array}$ & $\begin{array}{ll}\begin{array}{l}\text { Single } \\
\text { bioreactor }\end{array} & \text { (SMBR), } \\
\text { Sand } & \text { filtration, } \\
\text { Membrane } & \text { filtration, } \\
\text { Struvite crystallizer } \\
\text { and Zeolite adsorption }\end{array}$ & $\begin{array}{l}\text { Up-flow } \\
\text { anaerobic } \\
\text { sludge } \\
\text { blanket } \\
\text { reactor } \\
\text { (UASB) }\end{array}$ & $\begin{array}{l}\text { Optimal } \\
\text { configuration } \\
\text { of WW } \\
\text { treatment } \\
\text { and biogas } \\
\text { recovery }\end{array}$ & Up to $50 \%$ & - \\
\hline Sun et al., 2020 & $\begin{array}{l}\text { Centralised- CAS \& } \\
\text { MBR, Decentralised- } \\
\text { UASB and Trickling } \\
\text { filter }\end{array}$ & UASB & $\begin{array}{l}\text { WW } \\
\text { treatment } \\
\text { and } \\
\text { maximizing } \\
\text { biogas } \\
\text { production }\end{array}$ & $\begin{array}{l}24 \% \text { (average) } \\
\text { of sludge } \\
\text { organic energy }\end{array}$ & - \\
\hline Soda et al., 2010 & $\begin{array}{l}\text { Incineration, Melting } \\
\text { and Landfill }\end{array}$ & $\mathrm{AD}$ & $\begin{array}{l}\text { Maximise } \\
\text { the biogas } \\
\text { production } \\
\text { and digested } \\
\text { sludge } \\
\text { disposal }\end{array}$ & Above $50 \%$ & $\begin{array}{l}\text { Sewage } \\
\text { sludge } \\
\text { treatment } \\
\text { plant in Osaka } \\
\text { (Japan) }\end{array}$ \\
\hline $\begin{array}{l}\text { Sarpong et al., } \\
2019\end{array}$ & $\begin{array}{l}\text { Enhanced } \\
\text { sedimentation, CAS, } \\
\text { Nitrification/anammox } \\
\text { and biofiltration }\end{array}$ & $\begin{array}{l}\text { AD (co- } \\
\text { digestion) }\end{array}$ & $\begin{array}{l}\text { Maximizing } \\
\text { energy and } \\
\text { nutrient } \\
\text { recover by } \\
\text { cost } \\
\text { minimization }\end{array}$ & $\begin{array}{l}35 \text { to }>100 \% \\
\text { based on the } \\
\text { treatment } \\
\text { process and } \\
\text { co-digestion }\end{array}$ & $\begin{array}{l}\text { Gresham } \\
\text { WWTP } \\
\text { (USA) and } \\
\text { Strass WWTP } \\
\text { (Austria) }\end{array}$ \\
\hline $\begin{array}{l}\text { Stillwell et al., } \\
2010\end{array}$ & - & $\begin{array}{l}\mathrm{AD} \text { and } \\
\text { Incineration }\end{array}$ & $\begin{array}{l}\text { Maximise } \\
\text { the Biogas } \\
\text { and } \\
\text { Incineration } \\
\text { heat }\end{array}$ & $3.0-83 \%$ & $\begin{array}{l}\text { Texas } \\
\text { USA }\end{array}$ \\
\hline $\begin{array}{l}\text { Maalouf and El- } \\
\text { Fadel, } 2020\end{array}$ & $\begin{array}{l}\text { Aerobic (CAS) and } \\
\text { Anaerobic (anaerobic } \\
\text { lagoon and septic tank) }\end{array}$ & $\begin{array}{l}\mathrm{AD} \quad \text { and } \\
\text { Incineration }\end{array}$ & $\begin{array}{l}\text { Minimizing } \\
\text { cost and } \\
\text { carbon } \\
\text { emissions }\end{array}$ & $\begin{array}{l}31-96 \% \\
\text { (integrated } \\
\text { MSW) }\end{array}$ & $\begin{array}{l}\text { MSW and } \\
\text { WW in Beirut, } \\
\text { Lebanon }\end{array}$ \\
\hline
\end{tabular}




\begin{tabular}{|c|c|c|c|c|c|}
\hline $\begin{array}{l}\text { Yang and Shen, } \\
2014\end{array}$ & - & $\mathrm{AD}$ and $\mathrm{HP}$ & $\begin{array}{l}\text { Maximise } \\
\text { biogas and } \\
\text { heat recovery }\end{array}$ & $\begin{array}{l}8 \% \text { electricity } \\
\text { and up to } 50 \% \\
\text { heat }\end{array}$ & $\begin{array}{l}\text { Small } \\
\text { community in } \\
\text { USA }\end{array}$ \\
\hline $\begin{array}{l}\text { Kretschmer et } \\
\text { al., } 2016\end{array}$ & - & $\mathrm{AD}$ and $\mathrm{HP}$ & $\begin{array}{l}\text { Maximise } \\
\text { biogas and } \\
\text { heat recovery }\end{array}$ & Above $50 \%$ & $\begin{array}{l}\text { Municipal } \\
\text { WWTP in } \\
\text { Austria }\end{array}$ \\
\hline Larsen, 2015 & $\begin{array}{l}\text { Activated sludge } \\
\text { process, Annamox and } \\
\text { Mainstream process }\end{array}$ & $\begin{array}{l}\mathrm{AD} \text { and } \mathrm{HP} \\
\text { (from } \\
\text { sewer) }\end{array}$ & $\begin{array}{l}\text { Improve } \\
\text { Aeration and } \\
\text { maximise } \\
\text { biogas and } \\
\text { heat recovery }\end{array}$ & $30-40 \%$ & - \\
\hline Yang et al., 2016 & - & $\begin{array}{l}\text { Gasification } \\
\text { and } \\
\text { Combustion }\end{array}$ & $\begin{array}{l}\text { Syngas } \\
\text { generation }\end{array}$ & $25.4-28.4 \%$ & $\begin{array}{l}\text { Balingian and } \\
\text { Mannheim } \\
\text { WWTPs in } \\
\text { Germany }\end{array}$ \\
\hline $\begin{array}{l}\text { Abourached } \\
\text { al., } 2016\end{array}$ & MFC & MFC & $\begin{array}{l}\text { Cost } \\
\text { minimization } \\
\text { of the } \\
\text { treatment } \\
\text { process and } \\
\text { energy } \\
\text { generation }\end{array}$ & $\begin{array}{l}40 \% \quad(\mathrm{MFC} \\
\text { efficiency in } \\
\text { electricity } \\
\text { generation) }\end{array}$ & $\begin{array}{l}\text { Food } \\
\text { processing } \\
\text { WW treatment } \\
\text { in San Joaquin } \\
\text { Vally, } \\
\text { California }\end{array}$ \\
\hline $\begin{array}{l}\text { Subha et al., } \\
2019\end{array}$ & $\begin{array}{lr}\text { Up-flow anaerobic } \\
\text { microbial fuel cell } \\
\text { (UAMFC) }\end{array}$ & UAMFC & $\begin{array}{l}\text { Maximizing } \\
\text { power } \\
\text { generation } \\
\text { from organic } \\
\text { fraction of } \\
\text { WW }\end{array}$ & $\begin{array}{l}40-60 \% \\
\left(104.9 \mathrm{~mW} / \mathrm{m}^{2}\right)\end{array}$ & $\begin{array}{l}\text { Muttathara } \\
\text { WWTP in } \\
\text { Trivandrum, } \\
\text { India }\end{array}$ \\
\hline
\end{tabular}

575 On the basis of the model analysed, we can conclude that the anaerobic digestion of sludge is 576 a widely explored option for electric recovery and heat pump for thermal energy recovery.

577 Although AD is widely used, it is highly recommended for medium to large scale WWTPs due 578 to its high sludge production rate and the high capital and operational cost of AD. Alongside 579 this, any WWTPs with poor quality sludge can co-digest the sludge with other locally available 580 organic waste to enhance the biogas production. This concept of co-digestion can also be 581 employed by small scale WWTPs by efficient planning. The other opportunity of energy 582 recovery for small plants with low sludge generation could be gasification, incineration 583 (combustion) and microalgae cultivation. These technologies can also be applied in 584 conjugation with $\mathrm{AD}$ at larger plants to reduce burden on landfills. Another energy recovery 585 technology is MFC, although seems efficient in energy generation, however further research is 586 required for its commercialization. Most of the energy recovery models seems to be plant 587 specific based on the treatment configuration and resource availability. These can only give an 588 overview of the available technologies, but none provide any benchmark for WW energy 589 recovery. There are no specific tools so far developed exclusively for energy recovery from the 590 WW, but some of these technologies are integrated with the renewable energy modelling tools 
like HOMER, RETScreen etc. The carbon reduction reported in Table 2 is expressed as the percentage of the energy demand supplied from the recovered energy in the respective study.

\section{Tools and opportunities for integrating local available renewable energy sources $\left(\mathbf{R}_{3}\right)$}

WWTPs have a good opportunity of generating its own energy from locally available renewable resources like hydropower (treated effluent) and solar energy. The use of locally available renewable energy sources can reduce the electricity supply from the grid and the relative $\mathrm{CO}_{2}$ emissions. A group of researchers evaluated the potential of micro hydropower (MHP) for WWTPs in Ireland and UK (Power et al., 2014). According to this study, flowrate of the WWTPs is of significance in hydro turbine installation. The seasonal variations (especially the rainfall and precipitation) and feed-in-tariffs of the respective geographic locations are said to influence the power output and economic viability of the hydropower system. Considering these, this study recommends MHP installation for large scale plants (due to high flow) and onsite utilization of the generated power(for low payback period). Fluctuation in the WW flow can be a rate limiting factor for MHP. To address this, a small scale WWTP "Kiheung Respia” in Yongin (South Korea) with highly fluctuated WW flow was investigated (Chae et al., 2015). MHP system of this study consists of effluent forebay tank to store the treated effluent and transfers it to the micro-turbine through the pressurized penstock (water level tracker), a system bypass that is used to divert the flow during very high flow conditions, self-induction generator and sensors to measure the flow. A semi-Kaplan turbine with adjustable blades and simple mechanical structure was used in this process due to its high efficiency and cost-effectiveness. According to this study, steady energy generation ranges within $57-123 \%$ of designed flow with $\left(0.35 \mathrm{~m}^{3} / \mathrm{s}\right)$ with turbine efficiency of $91.3 \%$ and overall electrical efficiency of $80.3 \%$. It also reported that the system can work below the designed flow $(<23 \%)$ at lower efficiency. The efficiency of the turbine in this study was interpreted by the hill-chart diagram plotted with the model performance and prototype turbine data at varying conditions. Although the electric efficiency of this system is high, it can only supply $0.83 \%$ of the total electricity demand of the plant annually. High flow adjustability of this model provides an opportunity for WWTPs with extreme flow variations to assess their power generation potential through MHP (Chae et al., 2015). Head of the turbine is also of significance in MHP generation. Considering this, an evaluation model was developed by Ak et al (2017) for Tatlar WWTP in Ankara (Turkey) using multicriteria fuzzy-logic tool. Kaplan and Archimedean 
screw are the two low-head hydropower technologies considered for this study. Archimedean screw turbine was reported as highly efficient low-head hydropower turbine. This is due to better power generation (34\% total energy demand of WWTP), low construction time (nine months) and payback period (2.4 years).

Chae and Kang (2013) assessed sustainability of the Kiheung Respia municipal WWTP in Korea by integrating the renewable energy technologies such as Solar PV (100kW), Small Hydropower (SHP) (10kW) and thermal energy recovery by heat pump (HP) (25 refrigeration ton). Solar energy is a green and affordable energy with inexhaustible and inherent nature and can benefit in long-term energy planning (Zhang et al., 2013). The total energy demand of 2\% was reported from solar PV positioned at optimum tilt angle. This was further increased to 6$8 \%$ by coating PV with super hydrophilic nanoparticles. Whereas, the SHP proved inefficient with very low energy generation $(<1 \%$ of total energy demand) due to low turbine head. Evaluation of thermal energy potential of this plant reported in thermal energy greater than the demand of the plant. The electricity generation potential of PV and SHP was analysed using RETScreen energy modelling tool, whereas the thermal energy recovery was manually calculated using mathematical equations from the literature. An ordinary least square regression model was developed by Yang et al (2020) to evaluate energy self-sufficiency of the WWTPs and guide the policy makers in constructing new WWTPs (medium scale) in China. According to this study, WWTPs with influent COD of 200-400 mg/L and flowrate of $55 \mathrm{~K} \mathrm{~m} 3 / \mathrm{d}$ are more likely to attain higher energy self-sufficiency. Above $35 \%$ of thermal energy and $20 \%$ of the electric energy generation potential was reported with further increase in this percentage by renewable energy integration. Feasibility of sludge incineration was suggested for WWTPs with sludge water content below $57 \%$.

Nguyen et al (2020) developed a power management model using Fuzzy-TOPSIS tool for optimal sizing of hybrid renewable energy and storage system for WWTPs. The optimal renewable energy configuration of the wind (5) and solar PV (165) was reported in $85 \%$ of the total energy demand of the plant considering economic and environmental demands. The total annual cost of this hybrid system was reported to be high with in electricity generation (AC) range of $10-70 \%$. This was further suggested to decrease with reduction in the load and number of wind turbines at the study location. Another group of researchers tried to improve the environmental sustainability of WW treatment plants through electricity supply from solar PV (Han et al., 2013). Solar PV used in this study was without any battery storage to make the process economical. Here, aerobic-anoxic-anaerobic treatment of WW was carried out in a 
single tank. The electricity supply from PV enhanced the aerobic and anoxic treatment of WW, thanks to the presence of sun (therefore electricity production) during the day and absence of sun in the night that led to anaerobic treatment of the WW. Finally, the resulted effluent of this process was proved efficient with great reduction in COD (88\%), ammoniacal nitrogen (98\%), total nitrogen $(70 \%)$ and total phosphorous reduction (83\%). Similarly, García-García et al (2015) evaluated electro-chemical treatment of industrial WW by power supply from ERDM 225TP/6 solar module with $1.50 \mathrm{~m}^{2}$ catchment area. Here, electro-coagulation (EC) of the WW was conducted in monopolar electro-chemical cell with copper electrodes (anode and cathode) in batches for 50 minutes with the current supply of 1-3 A. Followed by electro-oxidation process in batches with a boron-doped diamond anode and copper electrode for 180 minutes (3 hr). Application of electro-oxidation was initiated due to poor efficiency of organic carbon removal by the electro-coagulation. This combined technology resulted in reduction of $70 \%$ TOC, $99.7 \%$ COD, $100 \%$ (colour) and 95\% (turbidity) in the effluent. pH and current density of the process are reported as the significant factors for organic solids reduction in WW. A municipal WWTP in Benijing (China) with Anoxic-anaerobic-aerobic treatment evaluated its carbon neutrality by energy recovery (AD, heat pump) and renewable energy generation (solar PV) (Hao et al., 2015). About 50\% of the plant electric and thermal energy supply was reported from anaerobic digestion of sludge and heat recovered from WW using heat pump. Whereas, the solar PV mounted on the top of the anaerobic digester contributed $10 \%$ of the total electricity demand of the plant. Another similar study was conducted by Taha and Al-Sa'ed (2017) for WWTPs in three Palestinian cities- Nablus, Al-Bireh and Altira. Conventional activated sludge, extended aeration and membrane bioreactor are the three WW treatment techniques at these plants that were supplied with the electricity from anaerobic digestion of sludge and solar PV. The power supply from PV was just a backup for emergency situations like power-cuts at pumping station. Supply of total electricity demand of the plant solar PV was reported as cost effective over Combined Heat and Power (CHP) of the biogas produced by AD. Alternatively, combination of grid connected CHP and off-grid solar PV was reported economical for the WWTPs in Palestine. Brandoni and Bošnjaković (2017) assessed the costeffectiveness of renewable energy integration with WWTPs (with ASP and MBR) in SubSaharan Africa for efficient treatment of WW and its reuse in the agriculture. The assessment was carried out using renewable energy modelling tool 'HOMER'. This software is specifically developed to assess the optimal hybrid microgeneration system. Solar PV, Wind and AD are the energy sources considered in assessing and developing a hybrid micro-generation system for Bahir Dar town in Ethiopia, Sub-Saharan region. Different scenarios such as (i) baseline 
690 (varying cost energy), (ii) emergency (use of diesel engine) and (iii) selling back the renewable 691 electricity generated to grid was analysed. This assessment reported in supply of 33-55\% of 692 the total energy demand of the plant from renewable energy system at high investment cost. 693 Ali et al (2020) demonstrated the energy generation potential and 100\% renewable electricity 694 utilization at WWTPs in Australia. Energy sources such as anaerobic digestion of sludge, 695 biomass energy, solar energy (rooftop and centralised), wind and hydro were considered 696 alongside the load-shifting of the WWTPs. Some WWTPs practice load shifting i.e., partial storage of the daytime WW influent in a storage tanks and treating in the night when the electricity cost is low (Simon-Várhelyi et al., 2020). Data of 30 WWTPs in Australia was collected on hourly basis for a year from Geographic Information System (GIS) and was simulated in MATLAB environment. The load-shifting of six hours and electricity generation from wind (39\%), solar (29\%), sludge digestion (1\%) and biomass (31\%) was suggested to make WWTPs in Australia carbon free. An overview of different modelling studies on WW treatment optimization, energy recovery technology and renewable energy integration are given in Table 3.

Table 3: Overview of the models on WW treatment energy optimization, Energy recovery technologies and Renewables

\begin{tabular}{|c|c|c|c|c|c|c|}
\hline Reference & $\begin{array}{l}\text { WW } \\
\text { treatment } \\
\text { technique }\end{array}$ & $\begin{array}{l}\text { Energy } \\
\text { recovery } \\
\text { technology }\end{array}$ & $\begin{array}{l}\text { Renewable } \\
\text { technology }\end{array}$ & $\begin{array}{l}\text { Energy } \\
\text { optimization } \\
\text { goal }\end{array}$ & $\begin{array}{l}\text { Energy } \\
\text { generation }\end{array}$ & $\begin{array}{l}\text { Study } \\
\text { location }\end{array}$ \\
\hline $\begin{array}{l}\text { Power et al., } \\
2014\end{array}$ & $\begin{array}{l}\text { Not } \\
\text { specified, } \\
\text { however } \\
\text { mainly } \\
\text { based on } \\
\text { Activated }\end{array}$ & - & $\begin{array}{l}\text { Micro } \\
\text { hydropower } \\
(\mathrm{MHP})\end{array}$ & $\begin{array}{l}\text { Minimisation } \\
\text { of flow } \\
\text { variation and } \\
\text { payback }\end{array}$ & Up to $50 \%$ & $\begin{array}{l}\text { Ireland } \\
\text { and UK }\end{array}$ \\
\hline $\begin{array}{l}\text { Chae et al., } \\
2015\end{array}$ & - & - & MHP & Effluent flow & $0.83 \%$ & $\begin{array}{l}\text { Kiheung } \\
\text { Respia } \\
\text { WWTP in } \\
\text { Yongin } \\
\text { (South } \\
\text { Korea }\end{array}$ \\
\hline $\begin{array}{l}\text { Ak et al., } \\
2017\end{array}$ & - & - & MHP & $\begin{array}{lr}\text { Type } & \text { of } \\
\text { turbine } & \text { and } \\
\text { payback } & \\
\text { period } & \end{array}$ & $34 \%$ & $\begin{array}{l}\text { Tatlar } \\
\text { WWTP in } \\
\text { Ankara } \\
\text { (Turkey) }\end{array}$ \\
\hline $\begin{array}{l}\text { Chae and } \\
\text { Kang et al., } \\
2013\end{array}$ & - & HP & $\begin{array}{l}\text { Solar PV and } \\
\text { Small } \\
\text { hydropower }\end{array}$ & $\begin{array}{l}\text { Optimizing } \\
\text { size of the } \\
\text { energy system }\end{array}$ & $\begin{array}{l}7-9 \% \\
\text { electricity and } \\
\text { over } 100 \% \\
\text { heat }\end{array}$ & $\begin{array}{l}\text { Kiheung } \\
\text { Respia } \\
\text { municipal } \\
\text { WWTP in } \\
\text { Korea }\end{array}$ \\
\hline $\begin{array}{l}\text { Han et al., } \\
2013\end{array}$ & $\begin{array}{l}\text { Oxidation } \\
\text { ditch }\end{array}$ & - & Solar PV & $\begin{array}{l}\text { COD, } \\
\text { Nitrogen and }\end{array}$ & $\begin{array}{l}100 \% \\
\text { electricity }\end{array}$ & - \\
\hline
\end{tabular}




\begin{tabular}{|c|c|c|c|c|c|c|}
\hline & & & & $\begin{array}{l}\text { Phosphorus } \\
\text { removal }\end{array}$ & & \\
\hline $\begin{array}{l}\text { García- } \\
\text { García et al., } \\
2015\end{array}$ & $\begin{array}{l}\text { Electro- } \\
\text { coagulation } \\
\text { and } \\
\text { Electro- } \\
\text { oxidation }\end{array}$ & - & Solar cell & $\begin{array}{l}\text { TOC, COD, } \\
\text { Colour and } \\
\text { Turbidity } \\
\text { removal }\end{array}$ & $100 \%$ & - \\
\hline $\begin{array}{l}\text { Hao et al., } \\
2015\end{array}$ & - & $\mathrm{AD}$ and $\mathrm{HP}$ & Solar PV & $\begin{array}{l}\text { Energy } \\
\text { generation } \\
\text { process }\end{array}$ & upto $60 \%$ & $\begin{array}{l}\text { Municipal } \\
\text { WWTP in } \\
\text { Benijing } \\
\text { (China) }\end{array}$ \\
\hline $\begin{array}{l}\text { Brandoni } \\
\text { and } \\
\text { Bošnjaković, } \\
2016\end{array}$ & $\begin{array}{l}\text { Activated } \\
\text { sludge } \\
\text { process and } \\
\text { Membrane } \\
\text { bioreactor }\end{array}$ & $\mathrm{AD}$ & $\begin{array}{l}\text { Solar PV and } \\
\text { Wind }\end{array}$ & $\begin{array}{l}\text { Optimal } \\
\text { combination of } \\
\text { energy sources }\end{array}$ & $33-55 \%$ & $\begin{array}{l}\text { Bahir } \\
\text { Dahr, } \\
\text { Ethiopia, } \\
\text { Africa }\end{array}$ \\
\hline $\begin{array}{l}\text { Taha and } \\
\text { Al-Sa'ed, } \\
2017\end{array}$ & $\begin{array}{l}\text { Activated } \\
\text { sludge } \\
\text { process, } \\
\text { Extended } \\
\text { aeration } \\
\text { and } \\
\text { Membrane } \\
\text { bioreactor }\end{array}$ & $\mathrm{AD}$ & Solar PV & $\begin{array}{l}\text { Energy } \\
\text { generation } \\
\text { process }\end{array}$ & $9-15 \%$ & $\begin{array}{l}\text { WWTPs } \\
\text { in } \\
\text { Palestinian }\end{array}$ \\
\hline $\begin{array}{l}\text { Yang et al., } \\
2020\end{array}$ & $\begin{array}{l}\text { Anaerobic- } \\
\text { Anoxic- } \\
\text { Aerobic } \\
\text { (AAO) } \\
\text { process }\end{array}$ & $\begin{array}{l}\text { Incineration } \\
\text { and HP }\end{array}$ & Solar PV & $\begin{array}{l}\text { Optimal } \\
\text { combination of } \\
\text { energy } \\
\text { generation at } \\
\text { source (WW } \\
\text { and } \\
\text { renewables) }\end{array}$ & Above $40 \%$ & $\begin{array}{l}\text { WWTPs } \\
\text { in China }\end{array}$ \\
\hline $\begin{array}{ll}\text { Nguyen } & \text { et } \\
\text { al., 2020 } & \end{array}$ & - & - & $\begin{array}{l}\text { Solar PV, } \\
\text { Wind, } \\
\text { battery and } \\
\text { hydrogen } \\
\text { storage }\end{array}$ & $\begin{array}{l}\text { Optimal } \\
\text { combination of } \\
\text { renewable } \\
\text { energy and } \\
\text { storage system }\end{array}$ & $\begin{array}{l}\text { Approximately } \\
85 \%\end{array}$ & $\begin{array}{l}\text { WWTP in } \\
\text { Vietnam }\end{array}$ \\
\hline $\begin{array}{l}\text { Ali et al., } \\
2020\end{array}$ & NA & $\mathrm{AD}$ & $\begin{array}{l}\text { Solar PV, } \\
\text { Wind and } \\
\text { Hydropower }\end{array}$ & $\begin{array}{l}\text { Load-shifting } \\
\text { and optimal } \\
\text { combination of } \\
\text { renewable } \\
\text { energies }\end{array}$ & $69 \%$ & $\begin{array}{l}\text { WWTPs } \\
\text { in } \\
\text { Australia }\end{array}$ \\
\hline
\end{tabular}

708 Most studies on WWTP energy integration have focused on solar energy, since it is the most 709 economic and widely applicable. Modelling studies on micro hydropower mentioned in this section opens room of opportunity for WWTPs to become energy self-sufficient and carbon neutral. But, the MHP is highly suitable for WWTPs with high flow rates i.e., for larger

712 WWTPs than the smaller ones. Larger WWTPs can be transformed to energy self-sufficient by 713 WW energy recovery and renewable energy integration. Whereas, the small scale WWTPs with 714 high energy demand and low/no scope of energy recovery from wastewater can be sustainable 715 and energy self-sufficient by integration of renewable energy sources locally available. The idea of solar energy systems integrated with energy intensive treatment processes may be 
replicated at the plants that are economically weak (like decentralised WW treatment and small-scale WWTPs). WWTPs that have already optimized the treatment processes and devices and partially supply the energy demand by WW energy recovery can evaluate the renewable energy potential of the plant using different energy modelling tools like HOMER and RETScreen. Load-shifting of WWTPs as per the design of the WWTP can also serve as one of the good options for cost cutting in WWTPs. Although, load-shifting reduces the cost of the WW treatment, it still contributes to carbon emissions due to electricity supply from grid (fossil fuel-based electricity).

\section{Comparison of energy optimisation modelling tools and strategies for WWTP decarbonisation}

Table 4 compares the main characteristics of all the models developed so far for the study of the use of energy in wastewater treatment facilities. The references reported in the previous Tables have been reported in Table 4 for a full comparison and to provide further information on different tools. Table 4 shows different categories: model type, modelling environment used (when specified), purpose of study, optimization goal, Water-Energy nexus focus, time frame, time series, validation, applicability and $\mathrm{CO}_{2}$ reduction potential of the study. The category "Model type" gives information about the type of the model i.e., regression model or kinetic model or superstructure model or chemical equilibrium model etc, used in addressing the nexus issue by the respective studies. Main reason behind developing the model or tool i.e., parameters, technologies, treatment conditions etc are categorised as "Purpose of study". The aim of the decarbonisation strategies (energy optimization) analysed such as energy reduction $\left(R_{1}\right)$, energy recovery $\left(R_{2}\right)$, renewable energy $\left(R_{3}\right)$ is reported in the "Decarbonisation strategy" column. The time series and time frame considered in developing the model/tool and its validation at any WWTPs or community are mentioned under the respective category name. Flexibility of the model in terms of applicability to different size of WWTPs and geographic location are given under "Applicability". The carbon emissions reduction (\%) of different modelling studies are calculated based on the results achieved from the individual studies such as reduction in energy consumption or percentage of the energy demand covered from local available renewable sources or energy recovered from wastewater. 
Table 4: Wastewater-Energy modelling studies by different researchers

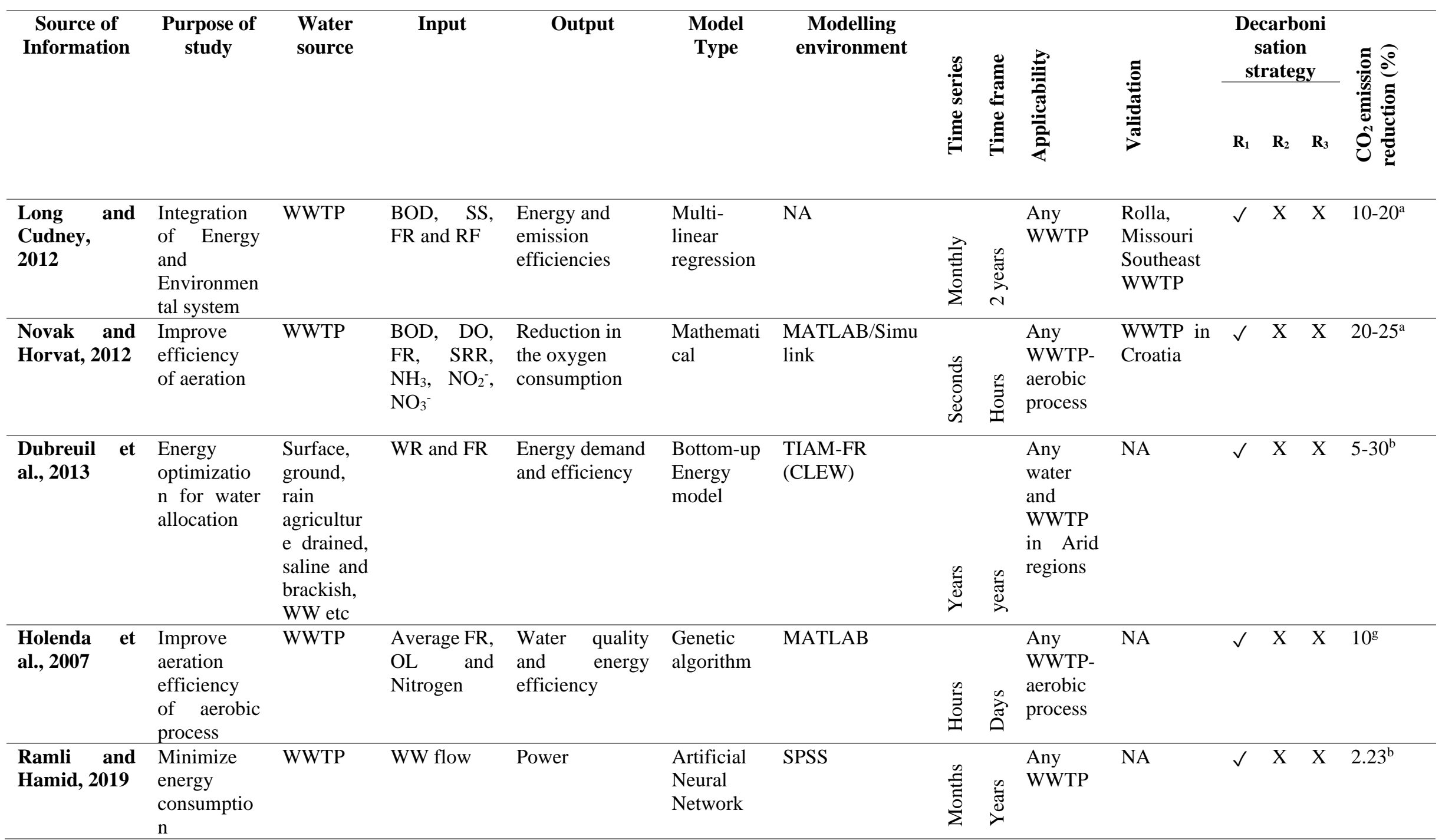




\begin{tabular}{|c|c|c|c|c|c|c|c|c|c|c|c|c|c|c|}
\hline $\begin{array}{l}\text { Cao and } \\
\text { Yang, 2020 }\end{array}$ & $\begin{array}{l}\text { Improving } \\
\text { aerobic/ano } \\
\text { xic } \\
\text { treatment }\end{array}$ & WWTP & $\begin{array}{l}\text { Influent and } \\
\text { effluent } \\
\text { quality, } \\
\text { weather data }\end{array}$ & $\begin{array}{l}\text { Treatment } \\
\text { efficiency }\end{array}$ & $\begin{array}{l}\text { Online } \\
\text { Sequential } \\
\text { Extreme } \\
\text { Learning } \\
\text { Machine } \\
\end{array}$ & MATLAB & $\hat{\vec{I}}^{n}$ & $\begin{array}{l}\frac{y}{d} \\
\frac{0}{3}\end{array}$ & $\begin{array}{l}\text { Any } \\
\text { WWTP } \\
\text { with } \\
\text { aerobic/ } \\
\text { anoxic }\end{array}$ & NA & $\checkmark$ & $\mathrm{X}$ & $X$ & $\begin{array}{l}\text { Up to } 40 \\
\text { b }\end{array}$ \\
\hline $\begin{array}{l}\text { Padrón-Páez } \\
\text { et al., } 2020\end{array}$ & $\begin{array}{l}\text { Sustainable } \\
\text { designing of } \\
\text { WWTPs }\end{array}$ & WWTP & $\begin{array}{l}\text { Quality and } \\
\text { quantity of } \\
\text { WW, } \\
\text { regional } \\
\text { regulation }\end{array}$ & $\begin{array}{l}\text { Level of } \\
\text { treatment, } \\
\text { optimum } \mathrm{WW} \\
\text { flowrates }\end{array}$ & $\begin{array}{l}\text { MINLP, } \\
\text { Lexicogra } \\
\text { phic, } \quad \epsilon \\
\text { constraints } \\
\text { and } \\
\text { TOPSIS }\end{array}$ & $\begin{array}{l}\text { MATLAB and } \\
\text { GAMS }\end{array}$ & ' & 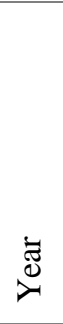 & $\begin{array}{l}\text { Any } \\
\text { WWTP } \\
\text { focusing } \\
\text { on } \\
\text { sustaina } \\
\text { ble } \\
\text { treatmen } \\
\text { t }\end{array}$ & NA & $\checkmark$ & $\mathrm{X}$ & $X$ & $\begin{array}{l}\mathrm{Up} \text { to } \\
20.2^{\mathrm{k}}\end{array}$ \\
\hline $\begin{array}{l}\text { Molinos- } \\
\text { Senante et } \\
\text { al., } 2015\end{array}$ & $\begin{array}{l}\text { Account the } \\
\mathrm{CO}_{2} \\
\text { emission } \\
\text { price }\end{array}$ & WWTP & $\begin{array}{l}\text { Compositio } \\
\mathrm{n} \text { of the WW } \\
\& \text { FR }\end{array}$ & GHG emissions & $\begin{array}{l}\text { Directiona } \\
1 \text { distance } \\
\text { functional } \\
\text { approach }\end{array}$ & NA & $\overleftrightarrow{Z}$ & Z & $\begin{array}{l}\text { Any } \\
\text { WWTP }\end{array}$ & NA & $X$ & $\checkmark$ & $X$ & $>50^{\mathrm{a}}$ \\
\hline $\begin{array}{l}\text { Stillwell et } \\
\text { al., } 2010\end{array}$ & $\begin{array}{l}\text { Implementa } \\
\text { tion of } \\
\text { sustainable } \\
\text { energy } \\
\text { policy }\end{array}$ & WWTP & FR, DS & $\begin{array}{l}\text { Energy } \\
\text { recovery }\end{array}$ & $\begin{array}{l}\text { Mathemati } \\
\text { cal }\end{array}$ & NA & $\overleftrightarrow{z}$ & $\mathbb{Z}$ & $\begin{array}{l}\text { WWTP } \\
>5 \mathrm{mgd} \\
\text { (million } \\
\text { gallon } \\
\text { per day) }\end{array}$ & NA & $\mathrm{X}$ & $\checkmark$ & $X$ & $\begin{array}{l}\text { Texas=4 } \\
.7-83^{\mathrm{g}} ; \\
\text { US=2.6- } \\
27^{\mathrm{g}}\end{array}$ \\
\hline $\begin{array}{l}\text { Yang and } \\
\text { Shen, 2014 }\end{array}$ & $\begin{array}{l}\text { Energy } \\
\text { recover } \\
\text { using HP \& } \\
\text { SS-AD }\end{array}$ & $\begin{array}{l}\text { Sewers } \\
\text { (small } \\
\text { communit } \\
\text { y) }\end{array}$ & $\begin{array}{l}\text { FR, OL \& } \\
\text { WW } \\
\text { temperature }\end{array}$ & Thermal energy & NA & NA & $\hat{\vec{A}}^{n}$ & $\overleftrightarrow{Z}$ & $\begin{array}{l}\text { Large } \\
\text { flow } \\
\text { plants }\end{array}$ & $\begin{array}{l}1000 \\
\text { houses } \\
\text { residential } \\
\text { area in } \\
\text { USA }\end{array}$ & $X$ & $\checkmark$ & $\mathrm{X}$ & $8^{a}$ \\
\hline $\begin{array}{l}\text { Nowak et al., } \\
2015\end{array}$ & $\begin{array}{l}\text { Energy } \\
\text { recover } \\
\text { using AD \& } \\
\text { HP }\end{array}$ & WWTP & COD \& FR & Electricity & NA & NA & $\overleftrightarrow{z}$ & $\stackrel{\infty}{\grave{\Xi}}$ & $\begin{array}{l}\text { Any } \\
\text { WWTP }\end{array}$ & NA & $\mathrm{X}$ & $\checkmark$ & $X$ & $>50^{\mathrm{a}}$ \\
\hline $\begin{array}{l}\text { Khiewwijit et } \\
\text { al., } 2015\end{array}$ & $\begin{array}{l}\text { Potential of } \\
\text { energy and } \\
\text { nutrient } \\
\text { recovery }\end{array}$ & WWTP & $\begin{array}{l}\text { COD, } \mathrm{TN}, \\
\mathrm{TP}\end{array}$ & $\begin{array}{l}\text { Energy (electric } \\
\text { and thermal) } \\
\text { and } \mathrm{CO}_{2} \\
\text { emission } \\
\text { reduction }\end{array}$ & $\begin{array}{l}\text { Simulatio } \\
\mathrm{n}\end{array}$ & MS-Excel & 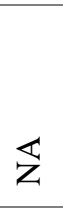 & Z & $\begin{array}{l}\text { Any } \\
\text { WWTP }\end{array}$ & NA & $X$ & $\checkmark$ & $\mathrm{X}$ & $35^{\mathrm{h}}$ \\
\hline
\end{tabular}




\begin{tabular}{|c|c|c|c|c|c|c|c|c|c|c|c|c|c|c|}
\hline $\begin{array}{l}\text { Yang et al., } \\
2016\end{array}$ & $\begin{array}{l}\text { Energy } \\
\text { recover by } \\
\text { thermal } \\
\text { technics }\end{array}$ & WWTP & OL \& SMC & Electric energy & $\begin{array}{l}\text { Chemical } \\
\text { equilibriu } \\
\mathrm{m}\end{array}$ & NA & $\mathbb{Z}$ & 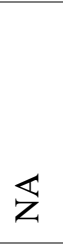 & $\begin{array}{l}\text { Any } \\
\text { WWTP } \\
\text { with } \\
\text { sludge } \\
\text { treatmen } \\
\mathrm{t}\end{array}$ & NA & $X$ & $\checkmark$ & $\mathrm{X}$ & $\begin{array}{l}25.4^{-} \\
28.4^{\mathrm{d}}\end{array}$ \\
\hline $\begin{array}{l}\text { Maalouf and } \\
\text { El-Fadel, } \\
2020\end{array}$ & $\begin{array}{l}\text { Integrated } \\
\text { waste } \\
\text { managemen } \\
\mathrm{t} \quad \text { and } \\
\text { emission } \\
\text { reduction }\end{array}$ & $\begin{array}{l}\text { Municipal } \\
\text { WW }\end{array}$ & $\begin{array}{l}\text { Quality and } \\
\text { quantity of } \\
\text { MSW and } \\
\text { WW, cost } \\
\text { modules of } \\
\text { respective } \\
\text { processes }\end{array}$ & $\begin{array}{l}\text { Cost of the } \\
\text { Integrated } \\
\text { waste } \\
\text { management, } \\
\text { emission } \\
\text { reduction }\end{array}$ & $\begin{array}{l}\text { Linear } \\
\text { optimizati } \\
\text { on }\end{array}$ & MS-Excel & 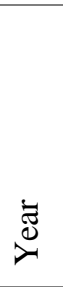 & 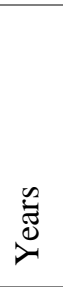 & $\begin{array}{l}\text { Any } \\
\text { Integrate } \\
d \quad \text { waste } \\
\text { manage } \\
\text { ment } \\
\text { system }\end{array}$ & NA & $X$ & $\checkmark$ & X & $30-90^{\mathrm{h}}$ \\
\hline $\begin{array}{l}\text { Power et al., } \\
2014\end{array}$ & $\begin{array}{l}\text { Evaluated } \\
\text { hydropower } \\
\text { generation } \\
\text { from } \\
\text { WWTP } \\
\text { outlet }\end{array}$ & WWTP & $\begin{array}{l}\text { flow rate } \\
\text { and head } \\
\text { pressure }\end{array}$ & $\begin{array}{l}\text { Electricity and } \\
\text { payback }\end{array}$ & Evaluation & NA & $\sum_{\tilde{D}}^{\infty}$ & 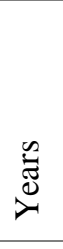 & $\begin{array}{l}\text { Large } \\
\text { WWTPs } \\
\text { in urban } \\
\text { area }\end{array}$ & NA & $X$ & $X$ & $\checkmark$ & $\begin{array}{l}\text { Up } \\
50^{d}\end{array}$ \\
\hline $\begin{array}{l}\text { Chae et al., } \\
2015\end{array}$ & $\begin{array}{l}\text { Application } \\
\text { of Hydro } \\
\text { power at } \\
\text { small scale } \\
\text { municipal } \\
\text { WWTPs }\end{array}$ & WWTP & FR, H & Electricity & $\begin{array}{l}\text { Hill-Chart } \\
\text { method }\end{array}$ & HydroHillChart & $\stackrel{\mathscr{0}}{\Xi}$ & 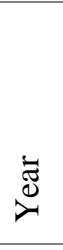 & $\begin{array}{l}\text { Small } \\
\text { scale } \\
\text { WWTPs }\end{array}$ & NA & $\mathrm{X}$ & $X$ & $\checkmark$ & $0.83^{\mathrm{d}}$ \\
\hline $\begin{array}{l}\text { Ak et al., } \\
2017\end{array}$ & $\begin{array}{l}\text { Evaluation } \\
\text { of low head } \\
\text { hydropower } \\
\text { technology }\end{array}$ & WWTP & $\begin{array}{l}\text { Turbine } \\
\text { head, FR, } \\
\text { flow } \\
\text { duration }\end{array}$ & $\begin{array}{l}\text { Investment cost, } \\
\text { payback period, } \\
\text { energy } \\
\text { generation } \\
\text { performance, } \\
\text { construction } \\
\text { duration, fish- } \\
\text { friendliness, } \\
\text { and aeration } \\
\text { capacity }\end{array}$ & $\begin{array}{l}\text { Fuzzy } \\
\text { logic }\end{array}$ & $\begin{array}{l}\text { MATLAB/Simu } \\
\text { link }\end{array}$ & 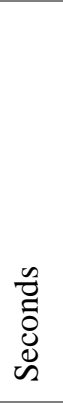 & 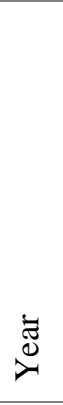 & $\begin{array}{l}\text { Low } \\
\text { head } \\
\text { effluent } \\
\text { discharg } \\
\text { e } \\
\text { WWTPs }\end{array}$ & NA & $\mathrm{X}$ & $X$ & $\checkmark$ & $<34^{\mathrm{d}}$ \\
\hline
\end{tabular}




\begin{tabular}{|c|c|c|c|c|c|c|c|c|c|c|c|c|c|c|}
\hline $\begin{array}{l}\text { Nguyen et al., } \\
2020\end{array}$ & $\begin{array}{l}\text { Optimal } \\
\text { sizing of } \\
\text { hybrid } \\
\text { renewable } \\
\text { energy and } \\
\text { storage } \\
\text { system }\end{array}$ & WWTP & $\begin{array}{l}\text { Energy } \\
\text { demand, } \\
\text { cost } \\
\text { modules, } \\
\text { wind speed, } \\
\text { solar } \\
\text { irradiance }\end{array}$ & $\begin{array}{l}\text { Cost, optimal } \\
\text { size, reliability } \\
\text { and } \mathrm{CO} 2 \\
\text { emissions of the } \\
\text { hybrid system }\end{array}$ & $\begin{array}{l}\text { Fuzzy- } \\
\text { TOPSIS }\end{array}$ & NA & 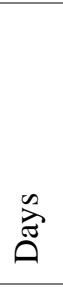 & $\stackrel{\varpi}{\varpi}$ & $\begin{array}{l}\text { Any } \\
\text { WWTP }\end{array}$ & NA & $X$ & $X$ & $\checkmark$ & $\begin{array}{l}\text { Around } \\
85^{\mathrm{d}}\end{array}$ \\
\hline $\begin{array}{l}\text { Kretschmer } \\
\text { et al., } 2016\end{array}$ & $\begin{array}{l}\text { Transform } \\
\text { WWTP into } \\
\text { regional } \\
\text { energy cell } \\
\text { (heat } \\
\text { recovery) }\end{array}$ & WWTP & $\begin{array}{l}\text { FR, OL, TN, } \\
\text { TP, TED, } \\
\text { EED, SHC }\end{array}$ & $\begin{array}{l}\text { Thermal (WW } \\
\text { through HP \& } \\
\text { AD) and } \\
\text { electric (AD) } \\
\text { energy } \\
\text { generated and } \\
\text { process energy } \\
\text { efficiency } \\
\text { (Aerobic) }\end{array}$ & $\begin{array}{l}\text { Process } \\
\text { network } \\
\text { synthesis } \\
\text { (PNS) }\end{array}$ & MS-Excel & $\stackrel{\mathscr{\Xi}}{\circlearrowright}$ & $\overleftrightarrow{z}$ & $\begin{array}{l}\text { Any } \\
\text { WWTP } \\
\text { with } \\
\text { sludge } \\
\text { treatmen } \\
\text { t }\end{array}$ & NA & $\checkmark$ & $\checkmark$ & $\mathrm{X}$ & $>50^{\mathrm{d}}$ \\
\hline $\begin{array}{l}\text { Soda et al., } \\
2010\end{array}$ & $\begin{array}{l}\text { Evaluation } \\
\text { of energy } \\
\text { consumptio } \\
\mathrm{n} \text { of sludge } \\
\text { treatment } \\
\text { plant }\end{array}$ & WWTP & $\begin{array}{l}\text { Sludge load, } \\
\text { WC, Solid } \\
\text { load }\end{array}$ & $\begin{array}{l}\text { Energy } \\
\text { efficiency of the } \\
\text { sludge } \\
\text { treatment and } \\
\text { thermal energy } \\
\text { recoverable }\end{array}$ & Analytical & NA & $\overbrace{\bar{\theta}}^{\infty}$ & $\overleftrightarrow{Z}$ & $\begin{array}{l}\text { Any } \\
\text { Sludge } \\
\text { treatmen } \\
\text { t plant }\end{array}$ & NA & $\checkmark$ & $\checkmark$ & $\mathrm{X}$ & $>50^{\mathrm{a}}$ \\
\hline Larsen, 2015 & $\begin{array}{l}\text { Evaluation } \\
\text { of } \mathrm{CO}_{2} \\
\text { neutrality } \\
\text { processes of } \\
\text { the WWTPs }\end{array}$ & $\begin{array}{l}\text { WWTP \& } \\
\text { Sewer }\end{array}$ & $\begin{array}{ll}\mathrm{COD}, & \mathrm{NH}_{3} \\
\& & \mathrm{WW} \\
\text { temperature }\end{array}$ & $\begin{array}{l}\text { Energy } \\
\text { efficiency, } \\
\text { recoverable } \\
\text { thermal energy, } \\
\mathrm{N}_{2} \mathrm{O} \& \mathrm{CH}_{4} \\
\text { emissions }\end{array}$ & NA & NA & $\overleftrightarrow{Z}$ & $\overleftrightarrow{Z}$ & $\begin{array}{l}\text { Any } \\
\text { WWTP }\end{array}$ & NA & $\checkmark$ & $\checkmark$ & $\mathrm{X}$ & $30-40^{\mathrm{a}}$ \\
\hline $\begin{array}{l}\text { Puchongkaw } \\
\text { arin et al., } \\
2015\end{array}$ & $\begin{array}{l}\text { Resource } \\
\text { recover } \\
\text { from WW }\end{array}$ & WWTP & $\begin{array}{l}\text { COD, } \quad \text { TN, } \\
\text { TSS \& TP }\end{array}$ & $\begin{array}{l}\text { Energy and } \\
\text { resources } \\
\text { recoverable }\end{array}$ & $\begin{array}{l}\text { Super } \\
\text { structure }\end{array}$ & $\begin{array}{l}\text { GPS-X }{ }^{\mathrm{TM}} \text { and } \\
\text { CAPDETWOR } \\
\text { KS }^{\mathrm{TM}}\end{array}$ & 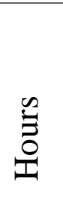 & 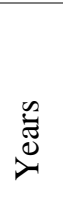 & $\begin{array}{l}\text { Any } \\
\text { WWTP }\end{array}$ & NA & $\checkmark$ & $\checkmark$ & $\mathrm{X}$ & $10-50^{\mathrm{d}}$ \\
\hline $\begin{array}{l}\text { Subha et al., } \\
2019\end{array}$ & $\begin{array}{l}\text { Simultaneo } \\
\text { us WW } \\
\text { treatment } \\
\text { and energy } \\
\text { generation }\end{array}$ & WWTP & $\begin{array}{l}\text { COD, OLR, } \\
\text { Flow rate }\end{array}$ & $\begin{array}{l}\text { Optimum OLR, } \\
\text { HRT, } \\
\text { Electricity } \\
\text { generated }\end{array}$ & $\begin{array}{l}\text { Monod } \\
\text { Kinetic } \\
\text { model }\end{array}$ & NA & 芫 & ڤે & $\begin{array}{l}\text { Any lab } \\
\text { scale } \\
\text { experim } \\
\text { ent }\end{array}$ & NA & $\checkmark$ & $\checkmark$ & $X$ & $40-60^{\text {id }}$ \\
\hline
\end{tabular}




\begin{tabular}{|c|c|c|c|c|c|c|c|c|c|c|c|c|c|}
\hline $\begin{array}{l}\text { Abourached } \\
\text { et al., } 2016\end{array}$ & $\begin{array}{l}\text { Cost } \\
\text { effective } \\
\text { WW } \\
\text { treatment } \\
\text { and } \\
\text { electricity } \\
\text { generation }\end{array}$ & WWTP & $\begin{array}{l}\text { Cost } \\
\text { modules, } \\
\text { HRT, COD, } \\
\text { flow rate }\end{array}$ & $\begin{array}{l}\text { Cost of WW } \\
\text { treatment and } \\
\text { electricity } \\
\text { generation by } \\
\text { MFC }\end{array}$ & NA & NA & 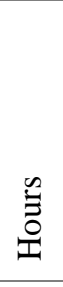 & $\overleftrightarrow{Z}$ & $\begin{array}{l}\text { Lab } \\
\text { scale }\end{array}$ & NA & $\checkmark$ & $\checkmark \quad X$ & $40^{\mathrm{i}}$ \\
\hline $\begin{array}{l}\text { Sun et al., } \\
2020\end{array}$ & $\begin{array}{l}\text { Centralised } \\
\text { and } \\
\text { decentralise } \\
\mathrm{d} \quad \text { WW } \\
\text { treatment } \\
\text { and energy } \\
\text { recovery } \\
\text { (AD) of } \\
\text { medium } \\
\text { scale } \\
\text { WWTPs }\end{array}$ & $\begin{array}{l}\text { Residenti } \\
\text { al WW } \\
\text { and } \\
\text { WWTP }\end{array}$ & $\begin{array}{l}\text { WW quality } \\
\text { (COD, TN, } \\
\text { TP), sludge } \\
\text { generated, } \\
\text { cost } \\
\text { modules of } \\
\text { WW } \\
\text { treatment } \\
\text { and energy } \\
\text { recovery }\end{array}$ & $\begin{array}{l}\text { Sustainability } \\
\text { (energy } \\
\text { generated, CO2 } \\
\text { reduced and } \\
\text { potential of } \\
\text { eutrophication) } \\
\text { and resilience }\end{array}$ & $\begin{array}{l}\text { Assessme } \\
\text { nt }\end{array}$ & $\begin{array}{l}\text { Analytical } \\
\text { Hierarchy } \\
\text { process }\end{array}$ & $\sum_{\overparen{A}}^{\infty}$ & $\begin{array}{l}n \\
\stackrel{\Xi}{0} \\
\Sigma\end{array}$ & $\begin{array}{l}\text { Regions } \\
\text { with } \\
\text { around } \\
30 \mathrm{~K} \mathrm{PE}\end{array}$ & NA & $\checkmark$ & $\checkmark \quad X$ & $24^{\mathrm{j}}$ \\
\hline $\begin{array}{l}\text { Longo et al., } \\
2019\end{array}$ & $\begin{array}{l}\text { Energy } \\
\text { benchmarki } \\
\text { ng of the } \\
\text { WWTP }\end{array}$ & WWTP & $\begin{array}{l}\text { Water flow, } \\
\text { Organic } \\
\text { load (COD), } \\
\text { TS, TSS, } \\
\text { TN, TP }\end{array}$ & $\begin{array}{l}\text { Energy } \\
\text { consumption } \\
\text { and load } \\
\text { reduction }\end{array}$ & $\begin{array}{l}\text { Mass- } \\
\text { balance }\end{array}$ & ENERWATER & $\frac{\lambda}{\bar{\Xi}}$ & $\overleftrightarrow{Z}$ & Any & NA & $\checkmark$ & $\mathrm{X}$ & $30-80^{\mathrm{df}}$ \\
\hline $\begin{array}{l}\text { Torrehrossa } \\
\text { et al., } 2018\end{array}$ & $\begin{array}{l}\text { Energy } \\
\text { optimizatio } \\
n \text { of WWTP }\end{array}$ & WWTP & $\begin{array}{l}\text { AFR, BOD, } \\
\text { biogas } \\
\text { composition } \\
\text {, sludge, pH } \\
\text { and digester } \\
\text { temperature }\end{array}$ & $\begin{array}{l}\text { Final pH \& } \\
\text { Temperature of } \\
\text { digester, SRT } \\
\text { and biogas } \\
\text { volume }\end{array}$ & $\begin{array}{l}\text { Fuzzy } \\
\text { logic, } \\
\text { Support } \\
\text { Vector } \\
\text { Regressio } \\
\text { n, Random } \\
\text { Forest and } \\
\text { Artificial } \\
\text { Neural } \\
\text { Network }\end{array}$ & $\begin{array}{l}\text { Energy Online } \\
\text { System (EOS) }\end{array}$ & $\stackrel{\lambda}{\bar{\Xi}}$ & 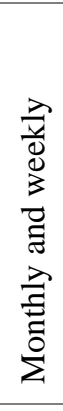 & $\begin{array}{l}\text { WWTPs } \\
\text { in } \\
\text { Europea } \\
\mathrm{n} \text { Union } \\
\text { only }\end{array}$ & $\begin{array}{l}\text { Burg- } \\
\text { Solingen } \\
\text { (Germany } \\
\text { ) and } \\
\text { Hidden- } \\
\text { City } \\
\text { (Netherlan } \\
\text { ds) }\end{array}$ & $\checkmark$ & $\checkmark \quad X$ & $50-80^{\mathrm{df}}$ \\
\hline $\begin{array}{l}\text { Sarpong et } \\
\text { al., } 2019\end{array}$ & $\begin{array}{l}\text { Evaluation } \\
\text { of energy } \\
\text { self- } \\
\text { sufficiency } \\
\text { of the small }\end{array}$ & WWTP & $\begin{array}{l}\text { Influent and } \\
\text { effluent } \\
\text { COD, } \\
\text { Nitrogen } \\
\text { and }\end{array}$ & $\begin{array}{l}\text { Energy } \\
\text { consumption, } \\
\text { energy recovery } \\
\text { and energy self- } \\
\text { sufficiency }\end{array}$ & $\begin{array}{l}\text { Mass- } \\
\text { balance }\end{array}$ & NA & 今ે & $\stackrel{\nabla}{\nexists}$ & $\begin{array}{l}\text { Small } \\
\text { scale } \\
\text { WWTPs }\end{array}$ & $\begin{array}{l}\text { Gresham } \\
\text { WWTP } \\
\text { (USA) and } \\
\text { Strass }\end{array}$ & $\checkmark$ & $\checkmark \quad X$ & $\begin{array}{l}35 \text { to } \\
>100^{\mathrm{d}}\end{array}$ \\
\hline
\end{tabular}




\begin{tabular}{|c|c|c|c|c|c|c|c|c|c|c|c|c|c|c|}
\hline & $\begin{array}{l}\text { scale } \\
\text { WWTPs }\end{array}$ & & $\begin{array}{l}\text { Phosphorus, } \\
\text { Cost } \\
\text { modules of } \\
\text { WW } \\
\text { treatment } \\
\text { and energy } \\
\text { recovery }\end{array}$ & & & & & & & $\begin{array}{l}\text { WWTP } \\
\text { (Austria) }\end{array}$ & & & & \\
\hline $\begin{array}{l}\text { Han et al., } \\
2013\end{array}$ & $\begin{array}{l}\text { Utilization } \\
\text { of RE for } \\
\text { aerobic } \\
\text { WWT } \\
\text { process }\end{array}$ & WWTP & $\begin{array}{l}\mathrm{COD}, \mathrm{NH}_{3^{-}} \\
\mathrm{N}, \mathrm{TN}, \mathrm{TP} \\
\& \quad \text { Solar } \\
\text { irradiance }\end{array}$ & $\begin{array}{l}\text { Portable water } \\
\text { and energy }\end{array}$ & $\begin{array}{l}\text { Prediction } \\
\text { model }\end{array}$ & NA & $\sum_{\overparen{D}}^{\infty}$ & $\overleftrightarrow{Z}$ & $\begin{array}{l}\text { Solar } \\
\text { resource } \\
\text { availabl } \\
\text { e } \\
\text { WWTP }\end{array}$ & NA & $\checkmark$ & $X$ & $\checkmark$ & $100^{e}$ \\
\hline $\begin{array}{l}\text { García- } \\
\text { García et al., } \\
2015\end{array}$ & $\begin{array}{l}\text { Effective } \\
\text { pollutant } \\
\text { removal } \\
\text { from } \\
\text { Industrial } \\
\text { WW and } \\
\text { energy } \\
\text { generation }\end{array}$ & WWTP & $\begin{array}{l}\text { COD, TOC } \\
\text { and Solar } \\
\text { irradiance }\end{array}$ & $\begin{array}{l}\text { Clean/potable } \\
\text { water and } \\
\text { energy }\end{array}$ & $\begin{array}{l}\text { Mass- } \\
\text { balance }\end{array}$ & NA & $\stackrel{\stackrel{\Xi}{\Xi}}{:}$ & 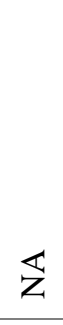 & $\begin{array}{l}\text { Industria } \\
1 \quad W W \\
\text { (solar } \\
\text { rich } \\
\text { regions) }\end{array}$ & NA & $\checkmark$ & $X$ & $\checkmark$ & $100^{\mathrm{e}}$ \\
\hline $\begin{array}{l}\text { Chae and } \\
\text { Kang, 2013 }\end{array}$ & $\begin{array}{l}\text { Energy self- } \\
\text { sufficient } \\
\text { WWTP }\end{array}$ & WWTP & $\begin{array}{l}\mathrm{T}, \mathrm{SHC}, \eta_{\mathrm{th}}, \\
\mathrm{FR}, \text { head of } \\
\text { turbine and } \\
\text { solar } \\
\text { irradiance }\end{array}$ & $\begin{array}{l}\text { Electrical } \\
(\mathrm{PV}+\mathrm{SHP}) \text { and } \\
\text { thermal (HP) } \\
\text { energy and } \\
\text { payback. }\end{array}$ & Evaluation & RETScreen & 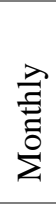 & $\frac{\lambda}{\bar{E}}$ & $\begin{array}{l}\text { Any } \\
\text { WWTP }\end{array}$ & NA & $X$ & $\checkmark$ & $\checkmark$ & $\begin{array}{l}\mathrm{Up} \\
5 \%{ }^{\mathrm{d}}\end{array}$ \\
\hline $\begin{array}{l}\text { Hao et al., } \\
2015\end{array}$ & $\begin{array}{l}\text { To Achieve } \\
\text { Energy } \\
\text { neutral } \\
\text { WWTP }\end{array}$ & WWTP & $\begin{array}{l}\text { COD, T \& } \\
\text { Solar } \\
\text { irradiance }\end{array}$ & $\begin{array}{l}\text { Electric and } \\
\text { thermal energy }\end{array}$ & Evaluation & NA & $\stackrel{\infty}{\grave{\Xi}}$ & 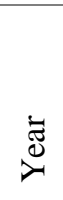 & $\begin{array}{l}\text { WWTPs } \\
\text { in China }\end{array}$ & $\begin{array}{l}\text { Municipal } \\
\text { WWTP in } \\
\text { Beijing, } \\
\text { China }\end{array}$ & $X$ & $\checkmark$ & $\checkmark$ & $\begin{array}{l}\mathrm{Up} \\
60^{\mathrm{d}}\end{array}$ \\
\hline $\begin{array}{l}\text { Brandoni } \\
\text { and } \\
\text { Bošnjaković, } \\
2016\end{array}$ & $\begin{array}{l}\text { To assess } \\
\text { cost } \\
\text { effectivenes } \\
\mathrm{s} \text { of } \\
\text { renewable } \\
\text { energy } \\
\text { integration } \\
\text { to WWTPs }\end{array}$ & WWTP & $\begin{array}{l}\text { Different } \\
\text { renewable } \\
\text { energy } \\
\text { system } \\
\text { efficiency, } \\
\text { cost and } \\
\text { lifespan }\end{array}$ & $\begin{array}{l}\text { Levelized cost } \\
\text { and } \\
\text { configuration of } \\
\text { the hybrid } \\
\text { energy system }\end{array}$ & $\begin{array}{l}\text { Assessme } \\
\text { nt }\end{array}$ & HOMER & $\stackrel{\mathscr{\Xi}}{\Xi}$ & $\stackrel{\mathscr{\Xi}}{\circlearrowright}$ & $\begin{array}{l}\text { WWTPs } \\
\text { in Sub- } \\
\text { Saharan } \\
\text { Africa }\end{array}$ & NA & $\mathrm{X}$ & $\checkmark$ & $\checkmark$ & $33-55^{d}$ \\
\hline
\end{tabular}




\begin{tabular}{|c|c|c|c|c|c|c|c|c|c|c|c|c|c|c|}
\hline $\begin{array}{l}\text { Yang et al., } \\
2020\end{array}$ & $\begin{array}{l}\text { Energy self- } \\
\text { sufficiency } \\
\text { guide for } \\
\text { future } \\
\text { WWTPs }\end{array}$ & WWTP & $\begin{array}{l}\text { Influent } \\
\text { quality, flow } \\
\text { rate, WW } \\
\text { temperature, } \\
\text { surface area } \\
\text { for PV, } \\
\text { geographic } \\
\text { coordinates, } \\
\text { effluent } \\
\text { temperature }\end{array}$ & $\begin{array}{l}\text { Annual energy } \\
\text { consumption of } \\
\text { the plant, } \\
\text { annual excess } \\
\text { sludge } \\
\text { production and } \\
\text { carbon footprint } \\
\text { of the bioreactor }\end{array}$ & $\begin{array}{l}\text { Ordinary } \\
\text { least } \\
\text { square } \\
\text { regression } \\
\text { analysis }\end{array}$ & $\begin{array}{l}\text { MATLAB and } \\
\text { SPSS }\end{array}$ & $\vec{\Xi}$ & $\succsim$ & $\begin{array}{l}\text { WWTPs } \\
\text { in China }\end{array}$ & NA & $X$ & $\checkmark$ & $\checkmark$ & $>45^{\mathrm{d}}$ \\
\hline $\begin{array}{l}\text { Ali et al., } \\
2020\end{array}$ & $\begin{array}{l}\text { Zero carbon } \\
\text { WWTPs }\end{array}$ & WWTP & $\begin{array}{l}\text { WW } \\
\text { treatment } \\
\text { process, } \\
\text { Cost } \\
\text { modules, } \\
\text { weather data }\end{array}$ & $\begin{array}{l}\text { Energy demand, } \\
\text { Energy } \\
\text { generation } \\
\text { potential, } \\
\text { Optimal size of } \\
\text { the renewable } \\
\text { energy system }\end{array}$ & $\begin{array}{l}\text { Simulatio } \\
\mathrm{n} \text { model }\end{array}$ & $\begin{array}{ll}\text { GIS } & \text { and } \\
\text { MATLAB } & \end{array}$ & 壱 & 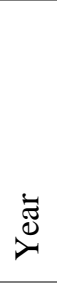 & $\begin{array}{l}\text { Any } \\
\text { WWTP }\end{array}$ & $\begin{array}{l}\text { WWTPs } \\
\text { in } \\
\text { Australia }\end{array}$ & $X$ & $\checkmark$ & $\checkmark$ & $69^{d}$ \\
\hline $\begin{array}{l}\text { Taha and Al- } \\
\text { Sa'ed, } 2017\end{array}$ & $\begin{array}{l}\text { To make } \\
\text { WWTP } \\
\text { energy } \\
\text { efficient }\end{array}$ & WWTP & $\begin{array}{l}\text { BOD, SS, } \\
\text { TN and } \\
\text { solar } \\
\text { irradiance }\end{array}$ & $\begin{array}{l}\text { Energy } \\
\text { efficiency and } \\
\text { energy } \\
\text { generated (PV) }\end{array}$ & $\begin{array}{l}\text { Assessme } \\
\text { nt }\end{array}$ & NA & $\overbrace{\bar{A}}^{\infty}$ & 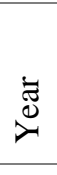 & NA & NA & $\checkmark$ & $\checkmark$ & $\checkmark$ & $9-15^{\mathrm{d}}$ \\
\hline $\begin{array}{l}\text { Zhang and } \\
\text { Vesselinov, } \\
2017\end{array}$ & WEF Nexus & $\begin{array}{l}\text { Ground, } \\
\text { susrface } \\
\text { and } \\
\text { recycled } \\
\text { (WWTP) }\end{array}$ & $\begin{array}{l}\text { Water, } \\
\text { energy and } \\
\text { food } \\
\text { demand, } \\
\text { availability } \\
\text { of coal and } \\
\text { natural gas, } \\
\text { water } \\
\text { resources }\end{array}$ & $\begin{array}{l}\text { Electricity and } \\
\text { Food } \\
\text { production }\end{array}$ & Linear & $\begin{array}{l}\text { Water-Energy- } \\
\text { Food security } \\
\text { nexus } \\
\text { Optimization } \\
\text { (WEFO) }\end{array}$ & 艺 & 艺 & NA & NA & $\mathrm{X}$ & $X$ & $\mathrm{X}$ & NA \\
\hline $\begin{array}{l}\text { Daher and } \\
\text { Mohtar, } 2015\end{array}$ & WEF Nexus & $\begin{array}{l}\text { Surface, } \\
\text { ground, } \\
\text { rain and } \\
\text { WWTP }\end{array}$ & $\begin{array}{l}\text { Types and } \\
\text { characteristi } \\
\text { cs of food, } \\
\text { water and } \\
\text { energy } \\
\text { system }\end{array}$ & $\begin{array}{l}\text { Water } \\
\text { requirement, } \\
\text { local energy } \\
\text { requirement, } \\
\text { low carbon } \\
\text { emissions, land } \\
\text { requirements, } \\
\text { financial }\end{array}$ & Dynamic & $\begin{array}{ll}\text { WEF } & \text { Nexus } \\
\text { Tool } 2.0 & \end{array}$ & $\overleftrightarrow{Z}$ & $\mathbb{Z}$ & NA & NA & $X$ & $\mathrm{X}$ & $\mathrm{X}$ & NA \\
\hline
\end{tabular}




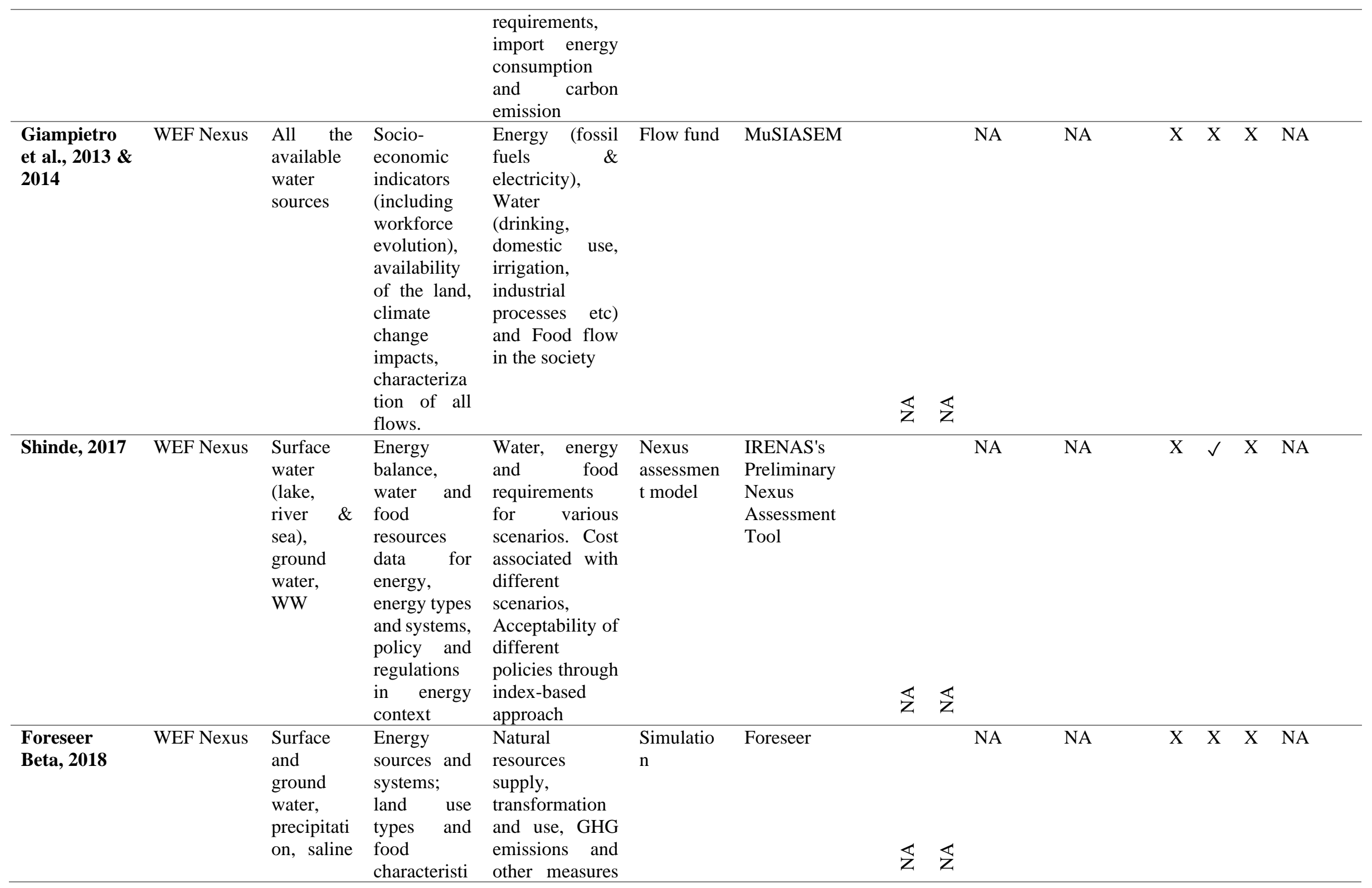




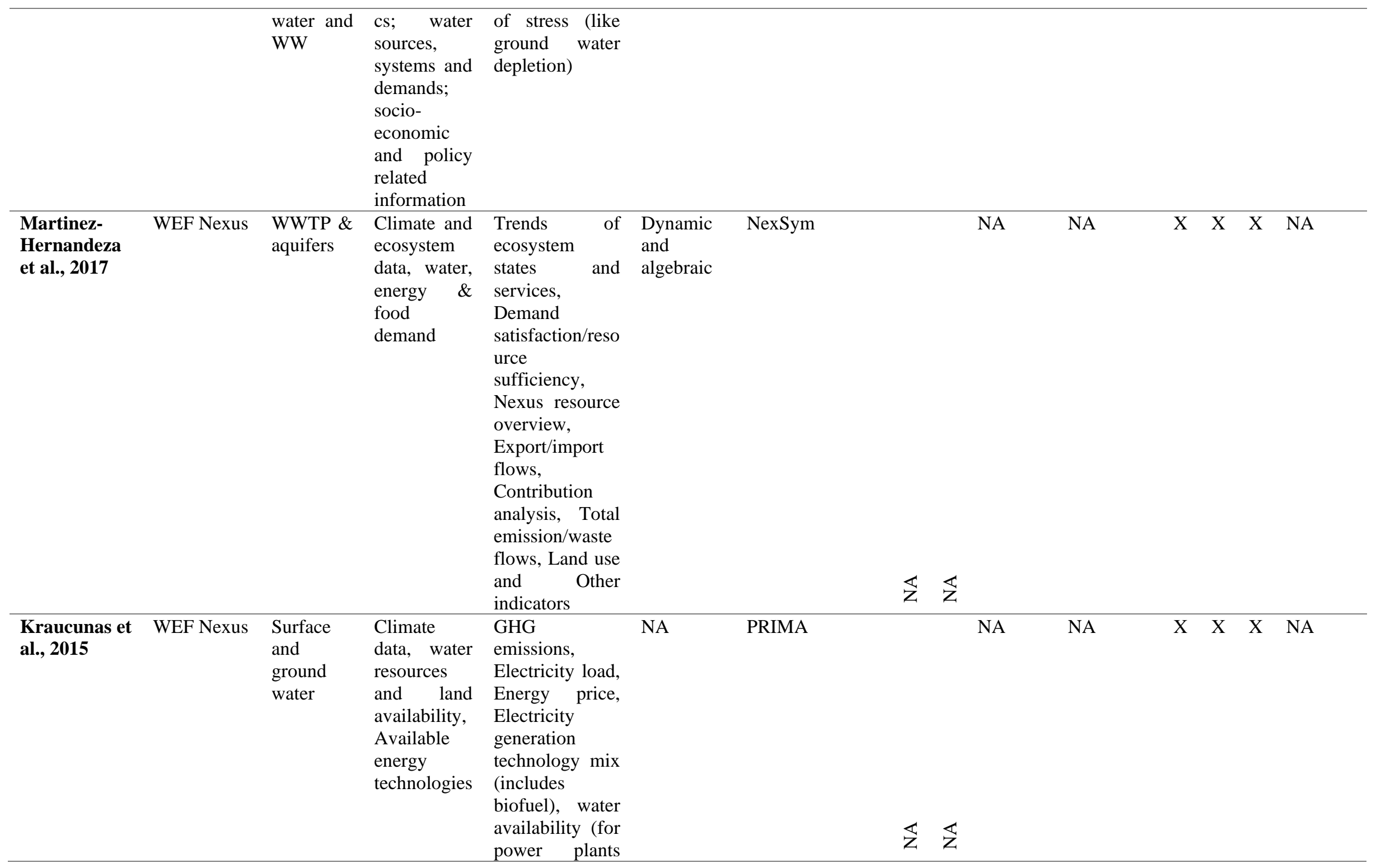


Note: $\mathrm{AFR}=\mathrm{Average}$ flow rate, $\mathrm{A}_{\mathrm{T}}=\mathrm{Alkalinity}, \mathrm{BOD}=\mathrm{Biochemical}$ oxygen demand, $\mathrm{COD}=\mathrm{Chemical}$ oxygen demand, $\mathrm{DO}=\mathrm{Dissolved}$ oxygen,

$\mathrm{DS}=$ Dry solid content, EED= Electric energy demand, ER=energy recovery, $\mathrm{FR}=$ flow rate, $\eta_{\text {th }}=$ Heat transfer efficiency, $\mathrm{NH}_{3}=\mathrm{Ammonia}$ Concentration, $\mathrm{NO}_{2}{ }^{-}=$Nitrite concentration, $\mathrm{NO}_{3}{ }^{-}=$Nitrate concentration, $\mathrm{OL}=$ Organic load, $\mathrm{RE}=\mathrm{Renewable}$ energies, $\mathrm{RF}=\mathrm{Rainfall} /$ precipitation, $\mathrm{SHC}=$ Specific heat capacity, $\mathrm{SMC}=$ Sludge moisture content, $\mathrm{SRR}=$ Sludge recycling rate, $\mathrm{SS}=$ suspended solids, T=Temperature of the effluent, $\mathrm{TED}=$ Thermal energy demand, $\mathrm{TN}=$ Total nitrogen, TOC=Total organic carbon, TP=Total phosphorus, $\mathrm{TSS}=\mathrm{Total}$ suspended solids, $\mathrm{VFA}=$ Volatile fatty acids, VSS=Volatile suspended solids, WC=Water content, WR=Water resources, SRT=Solid retention time, MTC $=$ Minimization of total cost of the system, MR=Maximizing revenue, UAMFC= Up-flow anaerobic microbial fuel cell. $\mathrm{a}=$ Reduction in energy consumption (\%) from (Georges et al., 2009); $\mathrm{b}=$ Reduction in energy consumption (\%) from (Panepinto et al., 2016); $\mathrm{c}=$ From (Hwang and Hanaki, 2000); d= Energy recovered or generated at site (\%); e= All the electricity required for the process is from Solar technology, considering $100 \%$ carbon emission reduction; $\mathrm{f}=($ Gude, 2015); $\mathrm{g}=$ Carbon emission reduction equivalent to reduction in the energy demand of WWTP $(\%) ; \mathrm{h}=$ Carbon reduction mentioned in the article; $\mathrm{i}=$ Electricity generation efficiency of the system $(\mathrm{Chen}$ et al., 2013$)$; $=\%$ of biogas produced; $\mathrm{k}=$ Energy reduction mentioned in the study. 
Very few studies have focused so far on the water and energy issues together. In addition to the models discussed in the previous sections, Table 4 reports additional nexus tools that involve water and energy as components of the tool, but they were developed for a different purpose, mainly understanding the nexus between the use of energy, water and food. For those tools it is not always possible to clearly gather detailed information such as the WW treatment techniques applied, energy recovery solutions from WW. These tools include IRENA's Preliminary Nexus Assessment Tool (Shinde, 2017), Water-Energy-Food Security Nexus Optimization (WEFO) (Zhang and Vesselinov, 2017), Water Food Energy Nexus Tool 2.0 (Daher and Mohtar, 2015), Multi-scale Integrated Analysis of Societal and Ecosystem Metabolism (MuSIASEM) (Giampietro et al., 2013, 2014), Forseer (Forseer beta, 2018), NexSym (Martinez-Hernandez et al., 2017) and Platform for Regional Integrated Modelling and Analysis (PRIMA) tool (Kraucunas et al., 2015).

Most of the studies shown in Table 4 are aimed at improving the WWT process efficiency along with energy and resource recovery. Models are mostly analytical or deterministic (Mass balance models) providing a clear view of underlying process mechanism and energy consumption of specific treatment techniques such as Aerobic process, electric energy recovery by $\mathrm{AD}$ and MFC, thermal energy recovery etc.

Main reason for grouping all the modelling studies in Table 4 is to compare the level of decarbonisation strategies (3R's) discussed in different studies and identify gap in existing energy decarbonisation tools for WWTP application. The expected carbon reduction of different modelling studies is further compared in Figure 7. As already mentioned, the energy intensity of the WWTP (including sludge treatment) differs from plant to plant based on the quality of influent WW, treatment techniques employed and its efficiency. The optimal configuration of the WW treatment (i.e., selection of the treatment techniques) based on the influent WW quality and desired effluent quality is suggested to reduce the carbon footprint of the plant up to $20 \%$ (Long and Cudney, 2012). Optimization of the equipment and machines involved in the WW treatment can further reduce the energy demand (Ramli and Hamid, 2019). Energy recovery from sludge using $\mathrm{AD}$ can reduce the $\mathrm{CO}_{2}$ emissions by $50 \%$ (MolinosSenante et al., 2015). The most frequently used and efficient biological treatment technique is the activated sludge process which is also the main energy consumer in the WW process. Improving the energy efficiency (optimizing) of the aeration process can reduced carbon emissions between the $10-30 \%$, as mentioned in the earlier sections and up to $40 \%$ with machine learning control strategies (Cao et Yang, 2020). When considering energy recovery 
technologies, $\mathrm{AD}$ is the most commonly used for electricity and heat generation. $\mathrm{AD}$ not only treats the organic content of the sludge generated at the WWTP, but also generates up to 50\% of the energy used by the plant based on (i) the energy content of the organic fraction of sludge and (ii) working conditions of the AD (Soda et al., 2010). Nowak et al (2015) reported that an increased energy efficiency of the AD by co-digestion of the sludge with other locally available organic waste can make WWTPs $100 \%$ carbon neutral. Integration of AD with other thermal techniques like incineration (under controlled conditions including gas capture) for sludge treatment can increase the energy production and reduce carbon footprint above 50 . The value depends on the sludge availability and regional regulation (Stillwell et al., 2010). Heat recovery from sewer WW (using heat pumps) can reduce carbon emissions of about 8\% (Yang and Shen, 2014). As already mentioned in the initial section of this paper that the thermal energy stored in the WW is higher than that demand, which can be supplied to the neighbourhood buildings (Kretschmer et al., 2016). WWTPs with less scope for organic energy recovery, especially small-scale WWTPs can reduce their carbon footprint in the range of 30-40\% by optimizing their aerobic treatment process and by thermal energy recovery through wastewater heat pumps (Larsen, 2015). Supply of the electricity from the solar PV towards the biological treatment process (Han et al., 2013) or electro-chemical treatment process (Garcia-Garcia et al., 2015) can reduce the carbon footprint of the specific treatment techniques due to electricity supply from the renewable resource (;), however storage would be needed in order to provide a continuous load and due to the low power density of PV systems, the solution would require an excessive investment and large area available to be able to cover the energy demand of the most common activated sludge plants. Installation of micro hydropower turbine at low head WWTPs can reduce carbon emissions related to grid power consumption of about $30 \%$ (Ak et al., 2017), whereas the same strategy at large flow plants (urban WWTPs) can reduce carbon emissions associated with electricity consumption of up to 50\% (Power et al., 2004). Integration of water pumps alone with solar PV can reduce 9-15\% of the total energy demand and related carbon emissions (Taha and AL-Sa'ed, 2017). Plants with low scope for biochemical process of energy recovery can apply techniques such as gasification/combustion, which not only generated energy in the range of $25-28 \%$, but also reduces the air emissions and reduces the waste volume to be disposed to landfill site (Yang et al., 2016).

Modelling studies on efficient WW treatment through electrochemical methods (García-García et al., 2015) and $\mathrm{A}^{2} \mathrm{O}$ (anoxic-anaerobic-oxic) process (Han et al., 2013) by electricity supply from solar PV have good $\mathrm{CO}_{2}$ reduction but are limited in application i.e., to lab-scale and 
825 small WWT facilities, respectively. Application of MFC (Subha et al., 2019) for electricity 826 generation and simultaneously treatment of WW has good potential to reduce carbon emission 827 from WW but are also limited similar to electro-chemical methods due to scalability issues. 828 The modelling works based on AD integration with heat pump (for heat recovery) (Yang and 829 Shen, 2014) or nutrient recover techniques (Khiewwijit et al., 2015) or aeration optimization 830 (Kretschmer et al., 2016) have achieved good carbon reduction efficiency, which ranges 831 between 40 to $60 \%$. Further, the carbon reduction efficiency of WWTPs can be improved (up 832 to $80 \%$ ) by integrating $\mathrm{AD}$ with thermo-chemical technologies like Pyrolysis, Gasification and 833 combustion, which not only helps in recovery of energy from the digested sludge, but also 834 reduces the quantity of sludge sent to landfills. Further, excess electricity generated at the 835 WWTPs can further be stored in hydrogen storage tank and can be utilised when required as 836 mentioned in Nguyen et al (2020). 


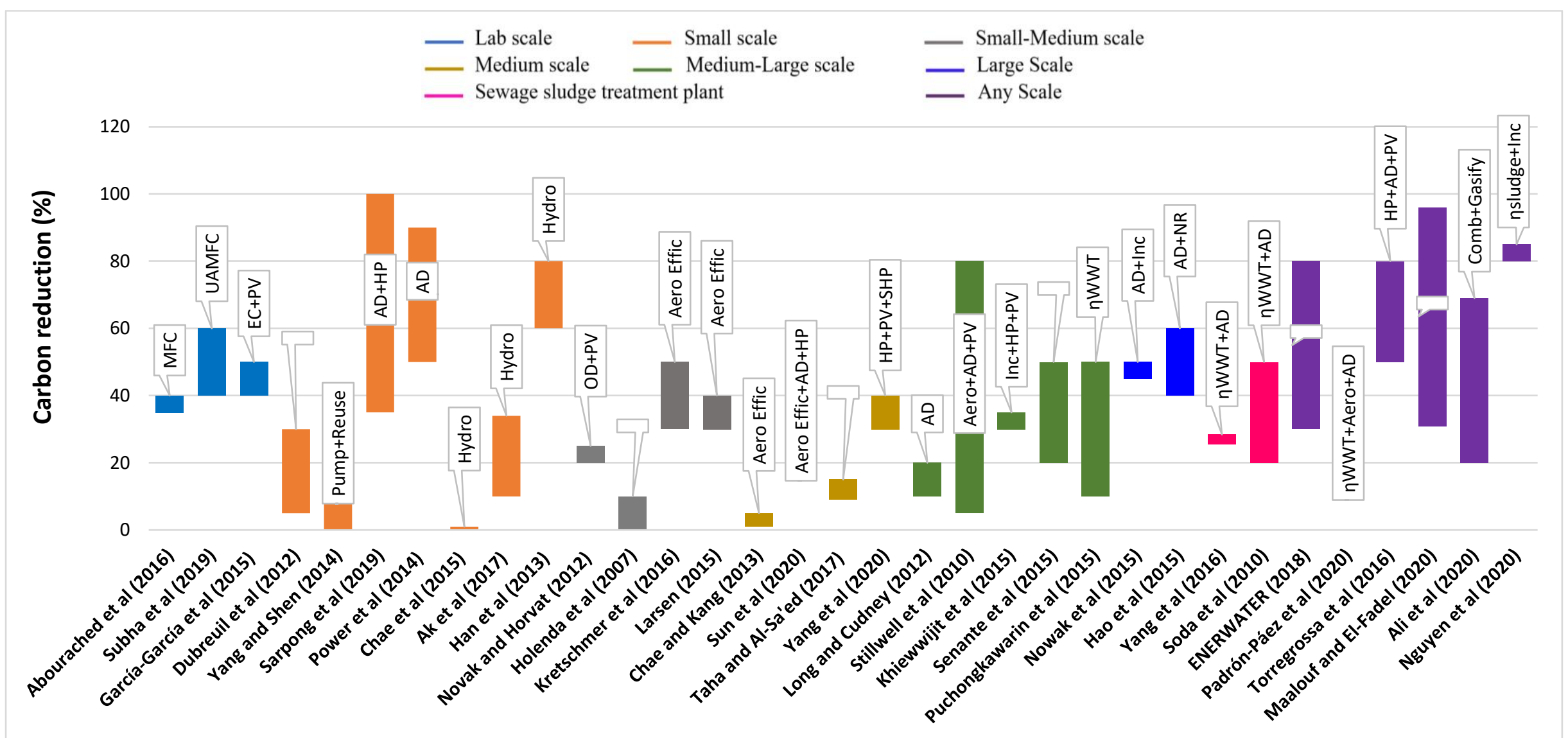

Figure 7. Carbon reduction of different modelling studies on Water-Energy Nexus of WWTPs

(Note $: \eta W W T=$ Improvement in the wastewater treatment process; $\mathrm{MFC}=$ Microbial fuel cell; $\mathrm{EC}=$ Electro-coagulation; $\mathrm{PV}=$ Solar photovoltaic 
digester; $\mathrm{HP}=$ Heat pump; Hydro= Hydro power; $\mathrm{OD}=$ Oxidation ditch; $\mathrm{SHP}=$ Small-scale hydropower; Inc= Incineration; NR= Nutrient recovery;

$843 \mathrm{Comb}=$ Combustion; Gasify $=$ Gasification; $\eta$ sludge = Improving the sludge treatment; $\mathrm{EB}=$ Energy benchmarking; LS= Load-shifting; $\mathrm{H}_{2}=$ 844 Hydrogen storage). 
WWTPs are reported as the highest energy consumers and $\mathrm{CO}_{2}$ emitters among the water industry, therefore it is important to access dedicated tools to investigate the best decarbonisation strategies for WWTPs. The study shows that identifying the perfect tool is not straightforward. Modelling tools available in literature have been developed with different purposes, either for improving the efficiency of the energy used by the facility or for integrating renewable energy sources. Furthermore, several modelling tools have been developed for specific WWTPs. Energy Online System is one of the few examples that could be widely applied for optimizing the use of energy intensive devices like pumps and blowers and improving the efficiency of AD. Another interesting tool is ENERWATER, an energy benchmarking model that can help wastewater managers to understand how efficient they use energy. However, the benchmarks used come from data collected from some European wastewater facilities and they are not always applicable to WWTPs belonging to other geographic areas.

The studies analysed in the present paper clearly indicate that the complete decarbonisation of the wastewater sector is possible, but only through the integration of both the energy saving and renewable energy production technologies. The challenge is to access a decision support tool that can help wastewater managers to identify all possible decarbonisation strategies and prioritise the investments. Although, there are dedicated energy optimisation tools like HOMER and RETscreen for renewable sources, such tools have not been developed for wastewater applications. It is not possible to link the energy demand to the main WW parameters and to assess energy saving initiatives. In authors' opinion there is still the need to develop a single platform able to understand how to reduce the energy demand of the wastewater process and to identify possible synergies between energy saving and renewable sources exploitable in the wastewater facilities. The possibility to understand with a single tool how to: i) use the excess electricity produced by intermittent renewable sources, ii) improve the efficiency of the wastewater treatments, iii) shift the electrical loads to minimise the energy consumption and iv) optimise the energy generation from programmable renewable sources, could, for example, increase the energy self-sufficiency of the WWTP and therefore show a better $\mathrm{CO}_{2}$ emission reduction and profitability of the entire investment. 
877 Authors are thankful to the University of Ulster and Horizon 2020 ALICE project. ALICE 878 project has received funding from the European Union's Horizon 2020 research and innovation 879 programme under the Marie Skłodowska-Curie grant agreement No 734560. This publication 880 reflects only the authors' view and the Research Executive Agency, REA, is not responsible 881 for any use that may be made of the information it contains.

\section{References}

Abourached, C., English, M.J. and Liu, H., 2016. Wastewater treatment by microbial fuel cell 884 (MFC) prior irrigation water reuse. J. Clean. Prod. 137, 144-149. http://dx.doi.org/10.1016/j.jclepro.2016.07.048

Ainger, C., Butler, D., Caffor, I., Crawford-Brown, D., Helm, D., Stephenson, T., 2009. A Low Carbon Water Industry in 2050. Resource Efficiency Programme. [online] Bristol: https://assets.publishing.service.gov.uk/government/uploads/system/uploads/attachment_data /file/291635/scho1209brob-e-e.pdf [Accessed 4 Jan. 2019].

Ak, M., Kentel, E., Kucukali, S., 2017. A fuzzy logic tool to evaluate low-head hydropower technologies at the outlet of wastewater treatment plants. Renew. Sust. Energ. Rev. 68, 727737. https://doi.org/10.1016/j.rser.2016.10.010

894

Allwood, J.M., Bajzelj, B., Curmi, E., Dennis, J., Fenner, R., Gilligan, C., Kopec, G., Linden, P., McMahon, R., Pyle, J., Ralph, D., Richards, K., 2012. Foreseer [computer software]. https://www.foreseer.group.cam.ac.uk/ (accessed 22 July 2017).AI-Megren, H.A., 2009. Hydrodesulfurization of thiophene over bimetallic Ni-Mo sulfide catalysts prepared by different methods. Arab. J. Sci. Eng. (Springer Science \& Business Media BV), 34.

Ali, S.M.H., Lenzen, M., Sack, F. and Yousefzadeh, M., 2020. Electricity generation and demand flexibility in wastewater treatment plants: Benefits for $100 \%$ renewable electricity grids. Appl Energy. 268, s114960. https://doi.org/10.1016/j.apenergy.2020.114960

Bala, B.K., 1997. Computer modelling of the rural energy system and of $\mathrm{CO}_{2}$ emissions for Bangladesh. Energy. 22 (10), 999-1003. https://doi.org/10.1016/S0360-5442(97)00025-X 
904

905

906

907

908

909

910

911

912

913

914

915

916

917

918

919

920

921

922

923

924

925

926

927

928

929

930

931

932

933

Batstone D J, Virdis B. The role of anaerobic digestion in the emerging energy economy. Curr Op in Biotechnol 2014; 27: 142-9. https://doi.org/10.1016/j.copbio.2014.01.013

Bernard, O., Hadj-Sadok, Z., Dochain, D., Genovesi, A., Steyer, J.P., 2001. Dynamical model development and parameter identification for an anaerobic wastewater treatment process. Biotechnol. Bioeng. 75 (4), 424-438. https://doi.org/10.1002/bit.10036

Boari, G., Mancini, I. M., \& Trulli, E. (1997). Technologies for water and wastewater treatment. Options Mediterraneennes. Serie A: Seminaires Mediterraneens (CIHEAM).

Brandoni, C., and Bošnjaković, B. (2017). HOMER analysis of the water and renewable energy nexus for water-stressed urban areas in Sub-Saharan Africa. Journal of cleaner production, 155, 105-118. https://doi.org/10.1016/j.jclepro.2016.07.114

Cao, W. and Yang, Q. (2020). Online Sequential Extreme Learning Machine Based Adaptive Control for Wastewater Treatment Plant. Neurocomputing. https://doi.org/10.1016/j.neucom.2019.05.109

Chae, K.J., Kang, J., 2013. Estimating the energy independence of a municipal wastewater treatment plant incorporating green energy resources. Energy Convers. Manag. 75, 664-672. https://doi.org/10.1016/j.enconman.2013.08.028

Chae, K.J., Kim, I.S., Ren, X., Cheon, K.H., 2015. Reliable energy recovery in an existing municipal wastewater treatment plant with a flow-variable micro-hydropower system. Energy Convers. Manag. 101, 681-688. https://doi.org/10.1016/j.enconman.2015.06.016

Chen, B.Y., Liu, S.Q., Hung, J.Y., Shiau, T.J., Wang, Y.M., 2013. Reduction of carbon dioxide emission by using microbial fuel cells during wastewater treatment. Aerosol Air Qual. Res. 13 (1), 266-274. https://doi.org/10.4209/aaqr.2012.05.0122

Cui, H., Ninomiya, Y., Masui, M., Mizukoshi, H., Sakano, T., Kanaoka, C., 2006. Fundamental behaviors in combustion of raw sewage sludge. Energy Fuels. 20, 77-83. https://doi.org/10.1021/ef050188d

Dürrenmatt, D.J., Wanner, O., 2014. A mathematical model to predict the effect of heat recovery on the wastewater temperature in sewers. Water Res. 48, 548-558. https://doi.org/10.1016/j.watres.2013.10.017 
Daher, B., Mohtar, R., 2015. Water-energy-food (WEF) Nexus Tool 2.0: guiding integrative resource planning and and decision-making.

Water

Int. 1-24. https://doi.org/10.1080/02508060.2015.1074148

937

Daw, J., Hallett, K., DeWolfe, J., Venner, I., 2012. Energy efficiency strategies for municipal wastewater treatment facilities (No. NREL/TP-7A20-53341). National Renewable Energy Laboratory (NREL), Golden, CO.

Dubreuil, A., Assoumou, E., Bouckaert, S., Selosse, S. and Maizi, N., 2013. Water modeling in an energy optimization framework - the water-scarce middle east context. Appl. Energy. 101, 268-279. http://dx.doi.org/10.1016/j.apenergy.2012.06.032.

ENERWATER, 2018. Enerwater Online Methodology V0 - Enerwater. [online] Available at: http://www.enerwater.eu/enerwater-online-methodology-v0/ [Accessed 1 Oct. 2018].

Fikar, M., Chachuat, B., Latifi, M.A., 2005. Optimal operation of alternating activated sludge processes. Control Eng. 13 (7), 853-861. https://doi.org/10.1016/j.conengprac.2004.10.003

Foreseer beta. (2018). Foreseer tool. [online] Available at: https://www.foreseer.group.cam.ac.uk/ [Accessed 19 Sep. 2018].

Frišták, V., Pipíška, M., Soja, G., 2018. Pyrolysis treatment of sewage sludge: a promising way to produce phosphorus fertilizer. J. Clean. Prod. 172, 1772-8. https://doi.org/10.1016/j.jclepro.2017.12.015

García-García, A., Martínez-Miranda, V., Martínez-Cienfuegos, I.G., Almazán-Sánchez, P.T., Castañeda-Juárez, M., Linares-Hernández, I., 2015. Industrial wastewater treatment by electrocoagulation-electrooxidation processes powered by solar cells. Fuel. 149, 46-54. https://doi.org/10.1016/j.fuel.2014.09.080

Georges, K., Thornton, A., Sadler, R., 2009. Transforming wastewater treatment to reduce carbon emissions. Resource Efficiency Programme. [online] Bristol: Environment Agency. Available https://assets.publishing.service.gov.uk/government/uploads/system/uploads/attachment_data /file/291633/scho1209brnz-e-e.pdf [Accessed 4 Jan. 2019].

Giampietro, M., Aspinall, R.J., Bukkens, S.G.F., Cadillo Benalcazar, J., Flammini, A., Gomiero, T., Kovacic, Z., Madrid, C., Ramos Martín, J. and Serrano Tovar, T. 2013a. An 
innovative accounting framework for the food-energy-water nexus: Application of the MuSIASEM approach to three case studies. FAO, Roma (Italia).

Giampietro, M., Aspinall, R., Ramos-Martín, J., Bukkens, S.G.F., 2013b. Resource accounting in sustainability assessments: establishing a nexus between land, water, food, energy and wealth using the MuSIASEM* approach.

Giampietro, M., Aspinall, R.J., Ramos-Martin, J. and Bukkens, S.G. eds. (2014). Resource accounting for sustainability assessment: The nexus between energy, food, water and land use. Routledge, UK.

Griffiths-Sattenspiel, B. and Wilson, W., 2009. The carbon footprint of water. River Network, Portland.

Gu, Y., Li, Y., Li, X., Luo, P., Wang, H., Robinson, Z.P., Wang, X., Wu, J., Li, F., 2017. The feasibility and challenges of energy self-sufficient wastewater treatment plants. Appl. energy, 204, 1463-1475. https://doi.org/10.1016/j.apenergy.2017.02.069

Gude, V.G., 2015. Energy and water autarky of wastewater treatment and power generation systems. Renew. Sust. Energy Rev. 45, pp.52-68. https://doi.org/10.1016/j.rser.2015.01.055

Hall, J. (1999) Ecological and economical balance for sludge management options. Problems around sludge, Session 3: Technology and innovative options related to sludge management, 18-19 November 1999, Stresa (Italy). European comession, 155-205.

Hall, L.M., Buckley, A.R., 2016. A review of energy systems models in the UK: Prevalent usage and categorisation. Appl. Energy. 169, 607-628. https://doi.org/10.1016/j.apenergy.2016.02.044

Han, C., Liu, J., Liang, H., Guo, X., Li, L., 2013. An innovative integrated system utilizing solar energy as power for the treatment of decentralized wastewater. J. Environ. Sci. 25 (2), 274-279. https://doi.org/10.1016/S1001-0742(12)60034-5

Hao, X., Liu, R., Huang, X., 2015. Evaluation of the potential for operating carbon neutral WWTPs in China. Water Res. 87, 424-431. https://doi.org/10.1016/j.watres.2015.05.050

Hernández-Chover, V., Castellet-Viciano, L. and Hernández-Sancho, F., 2020. Preventive maintenance versus cost of repairs in asset management: An efficiency analysis in wastewater treatment plants. Process Saf Environ. https://doi.org/10.1016/j.psep.2020.04.035 
1004

1005

1006

1007

1008

1009

1010

1011

1012

1013

1014

1015

1016

1017

1018

1019

1020

1021

1022

Hoff, H., 2011. Understanding the Nexus, Background Paper for the Bonn 2011 Conference: The Water, Energy and Food Security Nexus, Stockholm Environment Institute, Stockholm.

Holenda, B., Domokos, E., Redey, A., Fazakas, J., 2007. Aeration optimization of a wastewater treatment plant using genetic algorithm. Optim. Contr. Appl Met. 28 (3), 191-208. https://doi.org/10.1002/oca.796

Hwang, Y., Hanaki, K., 2000. The generation of $\mathrm{CO}_{2}$ in sewage sludge treatment systems: life cycle assessment. Water Sci. Technol. 41(8), 107-113. https://doi.org/10.2166/wst.2000.0149

Iacopozzi, I., Innocenti, V., Marsili-Libelli, S., \& Giusti, E. (2007). A modified Activated Sludge Model No. 3 (ASM3) with two-step nitrification-denitrification. Environmental Modelling \& Software, 22(6), 847-861. https://doi.org/10.1016/j.envsoft.2006.05.009

International Energy Agency (IEA) (2019) Global Energy and CO2 Status Report 2019. Paris, France: IEA. https://www.iea.org/reports/global-energy-co2-status-report-2019/emissions

IPCC, 2007. Climate Change 2007: Synthesis Report. Contribution of Working Groups I, II and III to the Fourth Assessment Report of the Intergovernmental Panel on Climate Change IPCC, Geneva, Switzerland.

Keller, J., Hartley, K., 2003. Greenhouse gas production in wastewater treatment: process selection is the major factor. Water Sci. Technol. 47 (12), 43-48. https://doi.org/10.2166/wst.2003.0626

Khiewwijit, R., Temmink, H., Rijnaarts, H., Keesman, K.J., 2015. Energy and nutrient recovery for municipal wastewater treatment: how to design a feasible plant layout?. Environ. Modell. Softw. 68, 156-165. https://doi.org/10.1016/j.envsoft.2015.02.011

Kraucunas, I., Clarke, L., Dirks, J., Hathaway, J., Hejazi, M., Hibbard, K., 2015. Investigating the nexus of climate, energy, water, and land at decision-relevant scales: the Platform for Regional Integrated Modeling and Analysis (PRIMA). Clim Change. 129, 573-88. https://doi.org/10.1007/s10584-014-1064-9.

Kretschmer, F., Neugebauer, G., Kollmann, R., Eder, M., Zach, F., Zottl, A., Narodoslawsky, M., Stöglehner, G., Ertl, T., 2016. Resource recovery from wastewater in Austria: wastewater treatment plants as regional energy cells. J. Water Reuse Desalination. 6 (3), 421-429. https://doi.org/10.2166/wrd.2015.119 
Larsen, T.A., 2015. $\mathrm{CO}_{2}$-neutral wastewater treatment plants or robust, climate-friendly wastewater management? A systems perspective. Water Res. 87, 513-521. https://doi.org/10.1016/j.watres.2015.06.006

Lee, U., Dong, J., Chung, J.N., 2016. Production of useful energy from solid waste materials by steam gasification. Int. J. Energy Res. 40, 1474-88. https://doi.org/10.1002/er.3529

1028

1029

1030

1031

1032

1033

1034

1035

1036

1037

1038

1039

1040

1041

1042

1043

1044

1045

1046

1047

1048

1049

Liu, H., Ramnarayanan, R., Logan, B.E., 2004. Production of electricity during wastewater treatment using a single chamber microbial fuel cell. Environ. Sci Technol. 38 (7), 2281-2285. https://doi.org/10.1021/es034923g

Long, S., Cudney, E., 2012. Integration of energy and environmental systems in wastewater treatment plants. Int. J. Energy Environ. 3, 521-530. https://doi.org/10.1155/2019/2621048

Longo, S., d'Antoni, B.M., Bongards, M., Chaparro, A., Cronrath, A., Fatone, F., Lema, J.M., Mauricio-Iglesias, M., Soares, A. and Hospido, A., 2016.

Longo, S., Mauricio-Iglesias, M., Soares, A., Campo, P., Fatone, F., Eusebi, A.L., Akkersdijk, E., Stefani, L. and Hospido, A., 2019. ENERWATER-A standard method for assessing and improving the energy efficiency of wastewater treatment plants. Appl Energy. 242, 897-910. https://doi.org/10.1016/j.apenergy.2019.03.130

Maalouf, A. and El-Fadel, M., 2020. A novel software for optimizing emissions and carbon credit from solid waste and wastewater management. Sci. Total Environ. 714, 136736. https://doi.org/10.1016/j.scitotenv.2020.136736

Monitoring and diagnosis of energy consumption in wastewater treatment plants. A state of the art and proposals for improvement. Appl Energy. 179, 1251-1268. https://doi.org/10.1016/j.apenergy.2016.07.043

Martinez-Hernandez, E., Leach, M., Yang, A., 2017. Understanding water-energy-food and ecosystem interactions using the nexus simulation tool NexSym. Appl. Energy. 206, 10091021. https://doi.org/10.1016/j.apenergy.2017.09.022

Mayhew, M., Stephenson, T., 1997. Low biomass yield activated sludge: a review. Environ Technol. 18 (9), 883-892. https://doi.org/10.1080/09593331808616607 
1050

1051

1052

1053

1054

1055

1056

1057

1058

1059

1060

1061

1062

1063

1064

1065

1066

1067

1068

1069

1070

1071

1072

1073

1074

1075

1076

1077

1078

1079

McCarty, P.L., Bae, J., Kim, J., 2011. Domestic wastewater treatment as a net energy producer-can this be achieved? Environ. Sci. Technol. 45, 7100-6. https://doi.org/10.1021/es2014264

Meegoda, J.N., Li, B., Patel, K., Wang, L.B., 2018. A review of the processes, parameters, and optimization of anaerobic digestion. Int. J. Environ Res Public Health. 15 (10), 2224. https://doi.org/10.3390/ijerph15102224

Metcalf and Eddy Ltd (2014). Wastewater Engineering: Treatment and Resource Recovery, 5th ed. McGraw-Hill, New York, NY, USA.

Mo, W., Zhang, Q., 2013. Energy-nutrients-water nexus: integrated resource recovery in municipal wastewater treatment plants. Journal of environmental management, 127, 255-267. https://doi.org/10.1016/j.jenvman.2013.05.007

Molinos-Senante, M., Hanley, N., Sala-Garrido, R., 2015. Measuring the $\mathrm{CO}_{2}$ shadow price for wastewater treatment: a directional distance function approach. Appl Energy. 144, 241-249. https://doi.org/10.1016/j.apenergy.2015.02.034

Nathanson, J.A. and Ambulkar, A. (2019) Wastewater treatment. Chicago: Encyclopaedia Britannica. Available from: https://www.britannica.com/technology/wastewater-treatment (accessed May 05, 2020).

Novak, M., Horvat, P., 2012. Mathematical modelling and optimisation of a waste water treatment plant by combined oxygen electrode and biological waste water treatment model. Appl. Math. Model. 36 (8), 3813-3825. https://doi.org/10.1016/j.apm.2011.11.028

Nowak, O., Enderle, P., Varbanov, P., 2015. Ways to optimize the energy balance of municipal wastewater systems: lessons learned from Austrian applications. J. Clean Prod. 88, 125-131. https://doi.org/10.1016/j.jclepro.2014.08.068

Nguyen, H.T., Safder, U., Nguyen, X.N. and Yoo, C., 2020. Multi-objective decision-making and optimal sizing of a hybrid renewable energy system to meet the dynamic energy demands $\begin{array}{llll}\text { of } & \text { w } & \text { wastewater } & 16570 .\end{array}$ https://doi.org/10.1016/j.energy.2019.116570

Palme, U.; Lundin, M.; Tillman, A. M.; Molander, S. Sustainable development indicators for wastewater systems - researchers and indicator users in a co-operative case study. Resour. Conserv. Recycl. 2005, 43, 293-311. https://doi.org/10.1016/j.resconrec.2004.06.006 
1080

1081

1082

1083

1084

1085

1086

1087

1088

1089

1090

1091

1092

1093

1094

1095

1096

1097

1098

1099

1100

1101

1102

1103

1104

1105

1106

1107

1108

1109

Panepinto, D., Fiore, S., Zappone, M., Genon, G. and Meucci, L., 2016. Evaluation of the energy efficiency of a large wastewater treatment plant in Italy. Appl Energy. 161, 404-411. https://doi.org/10.1016/j.apenergy.2015.10.027

Padrón-Páez, J.I., Almaraz, S.D.L. and Román-Martínez, A., 2020. Sustainable Wastewater Treatment Plants Design through Multiobjective Optimization. Comput Chem Eng. 140, 106850. https://doi.org/10.1016/j.compchemeng.2020.106850

Pasqualino, J.C., Meneses, M., Abella, M., Castells, F., 2009. LCA as a decision support tool for the environmental improvement of the operation of a municipal wastewater treatment

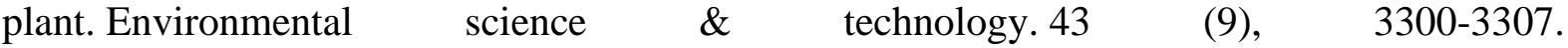
https://doi.org/10.1021/es802056r

Pfenninger, S., Hawkes, A., Keirstead, J., 2014. Energy systems modeling for twenty-first century energy challenges. Renew Sustain Energy Rev. 33, 74-86. https://doi.org/10.1016/j.rser.2014.02.003

PIER/EPRI technical report. Comparison of alternate cooling technologies for California power plants economic, environmental and other tradeoffs. In: Report no. 500-02-079F; 2002.

Power, C., McNabola, A., Coughlan, P., 2014. Development of an evaluation method for hydropower energy recovery in wastewater treatment plants: Case studies in Ireland and the UK. Sustain Energy Techn. 7, 166-177. https://doi.org/10.1016/j.seta.2014.06.001

Puchongkawarin, C., Gomez-Mont, C., Stuckey, D.C., Chachuat, B., 2015. Optimization-based methodology for the development of wastewater facilities for energy and nutrient recovery. Chemosphere. 140, 150-158. https://doi.org/10.1016/j.chemosphere.2014.08.061

Ramli, N. A., and Hamid, M. F.A.2019. Data Based Modeling of a Wastewater Treatment Plant by using Machine Learning Methods. J. Eng. Technol. 6, 14-21.

Sabia, G., Luigi, P., Avolio, F. and Caporossi, E., 2020. Energy saving in wastewater treatment plants: A methodology based on common key performance indicators for the evaluation of plant energy performance, classification and benchmarking. Energ Convers Manage. 220, 113067. https://doi.org/10.1016/j.enconman.2020.113067

Sarpong, G., Gude, V.G. and Magbanua, B.S., 2019. Energy autarky of small scale wastewater treatment plants by enhanced carbon capture and codigestion-A quantitative analysis. Energ Convers Manage. 199, 111999. https://doi.org/10.1016/j.enconman.2019.111999 
Shinde, V.R., 2017. Water-Energy-Food Nexus: Selected Tools and Models in Practice. WaterEnergy-Food Nexus: Principles and Practices. 229, 67.

Shizas, I., Bagley, D., 2004. Experimental Determination of Energy Content of Unknown Organics in Municipal Wastewater Streams. J. Eng. 130 (2), 45-53. https://doi.org/10.1061/(ASCE)0733-9402(2004)130:2(45)

Simon-Várhelyi, M., Cristea, V.M. and Luca, A.V., 2020. Reducing energy costs of the wastewater treatment plant by improved scheduling of the periodic influent load. Environ Manage. 262, 110294. https://doi.org/10.1016/j.jenvman.2020.110294

Situmorang, Y. A., Zhao, Z., Yoshida, A., Abudula, A., \& Guan, G. (2020). Small-scale biomass gasification systems for power generation $(<200 \mathrm{~kW}$ class $)$ : A review. Renewable and Sustainable Energy Reviews, 117, 109486. https://doi.org/10.1016/j.rser.2019.109486

Soda, S., Iwai, Y., Sei, K., Shimod, Y., Ike, M., 2010. Model analysis of energy consumption and greenhouse gas emissions of sewage sludge treatment systems with different processes and scales. Water Science and Technology. 61 (2), 365-373. https://doi.org/10.2166/wst.2010.827

Stillwell, A.S., Hoppock, D.C., Webber, M.E., 2010. Energy recovery from wastewater treatment plants in the United States: a case study of the energy-water nexus. Sustainability. 2 (4), 945-962. https://doi.org/10.3390/su2040945

Subha, C., Kavitha, S., Abisheka, S., Tamilarasan, K., Arulazhagan, P. and Banu, J.R., 2019. Bioelectricity generation and effect studies from organic rich chocolaterie wastewater using continuous upflow anaerobic microbial fuel cell. Fuel. 251, 224-232. https://doi.org/10.1016/j.fuel.2019.04.052

Sun, Y., Garrido-Baserba, M., Molinos-Senante, M., Donikian, N.A., Poch, M. and Rosso, D., 2020. A composite indicator approach to assess the sustainability of wastewater management alternatives. Sci. Total Environ. 138286. https://doi.org/10.1016/j.scitotenv.2020.138286

Sweetapple, C., Fu, G., Butler, D., 2013. Identifying key sources of uncertainty in the modelling of greenhouse gas emissions from wastewater treatment. Water Res. 47 (13), 46524665. https://doi.org/10.1016/j.watres.2013.05.021

Syed-Hassan, S.S.A., Wang, Y., Hu, S., Su, S., Xiang, J., 2017. Thermochemical processing of sewage sludge to energy and fuel: Fundamentals, challenges and considerations. Renew. Sustain. Energy Rev. 80, 888-913. https://doi.org/10.1016/j.rser.2017.05.262 
1140

1141

1142

1143

1144

1145

1146

1147

1148

1149

1150

1151

1152

1153

1154

1155

1156

1157

1158

1159

1160

1161

1162

1163

1164

1165

1166

1167

1168

Taha, M., Al-Sa'ed, R., 2017. Potential application of renewable energy sources at urban wastewater treatment facilities in Palestine: three case studies. http://hdl.handle.net/20.500.11889/5310

Torregrossa, D., Schutz, G., Cornelissen, A., Hernández-Sancho, F., Hansen, J., 2016. Energy saving in WWTP: daily benchmarking under uncertainty and data availability limitations. Environ. Res. 148, 330-337. https://doi.org/10.1016/j.envres.2016.04.010

Tyagi, V.K., Lo, S.L., 2013. Sludge: a waste or renewable source for energy and resources recovery. Renew. Sustain. Energy. Rev. 25, 708-28. https://doi.org/10.1016/j.rser.2013.05.029

United Nations Educational, Scientific and Cultural Organisation (UNESCO) (2017) Wastewater: the Untapped Resource. Durbane (South-Africa).

U.S. ENVIRONMENTAL PROTECTION AGENCY (USEPA), 2003. Wastewater Technology Fact Sheet Screening and Grit Removal.

U.S. ENVIRONMENTAL PROTECTION AGENCY (USEPA), 2013. Local Government Climate and Energy Strategy: Energy Efficiency in Water and Wastewater Facilities. Stony Point: Continuing Education and Development, Inc.

USDOE, 2014. The Water-Energy Nexus: Challenges and Opportunities. U.S. Department of Energy DOE/EPSA-0002.

van Loosdrecht, M.C.M., Brdjanovic, D., 2014. Anticipating the next century of wastewater treatment. Sci. 344 (6191), 1452-1453. https://doi.org/10.1126/science.1255183

Venkatesh, G., Chan, A., Brattebø, H., 2014. Understanding the water-energy-carbon nexus in urban water utilities: Comparison of four city case studies and the relevant influencing factors. Energy, 75, pp.153-166. https://doi.org/10.1016/j.energy.2014.06.111

Verstraete, W., Van de Caveye, P., Diamantis, V., 2009. Maximum use of resources present in domestic used water. Bioresour. Technol. 100 (23), 5537-45. https://doi.org/10.1016/j.biortech.2009.05.047

Werther, J., Ogada, T., 1999. Sewage sludge combustion. Prog. Energy. Combust. Sci. 25, 55116. https://doi.org/10.1016/S0360-1285(98)00020-3 
1169 World energy outlook 2019. (2019). Paris, France: Organization for Economic Co-operation and Development (OECD) / IEA.

1171 Yang, L., Shen, C., 2014. Integration of wastewater source heat pump and solid-state anaerobic 1172 digestion for residential waste treatment and energy production. Integration. 2 (5). 1173 https://doi.org/10.14304/SURYA.JPR.V2N5.1

1174 Yang, Q., Dussan, K., Monaghan, R.F., Zhan, X., 2016. Energy recovery from thermal 1175 treatment of dewatered sludge in wastewater treatment plants. Water Sci. Technol. 74 (3), $672-$ 1176 680. https://doi.org/10.2166/wst.2016.251

1177 Yang, X., Wei, J., Ye, G., Zhao, Y., Li, Z., Qiu, G., Li, F. and Wei, C., 2020. The correlations 1178 among wastewater internal energy, energy consumption and energy recovery/production 1179 potentials in wastewater treatment plant: An assessment of the energy balance. Sci. Total 1180 Environ. 714, 136655. https://doi.org/10.1016/j.scitotenv.2020.136655

1181 Yeh, D. and Prieto, A. L. (2011) Energy from Wastewater. Unpublished project meeting: 1182 Global Methane Initiative (GMI) Partnership-wide meeting, 12-14 October 2011, Krakow, 1183 Poland.

1184 Zhang, X., Vesselinov, V.V., 2017. Integrated modeling approach for optimal management of 1185 water, energy and food security nexus. Adv. Water Resour. 101, 1-10. 1186 https://doi.org/10.1016/j.advwatres.2016.12.017

1187 Zhang, Z.P., Du, F.H., 2013. Optimization and thermoeconomics research of a large reclaimed 1188 water source heat pump system. Sci. World J. 2013. https://doi.org/10.1155/2013/893020 